\title{
Changes in the nest sites of White Stork (Ciconia ciconia) in Hungary
}

\author{
Adrienn GYALuS $^{1 *}$, Zsolt VÉGVÁRI ${ }^{2} \&$ Tibor CsÖRGÖ ${ }^{1}$
}

Received: March 19, 2018 -Revised: June 22, 2018 -Accepted: June, 2018

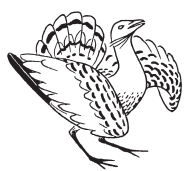

Adrienn Gyalus, Zsolt Végvári \& Tibor Csörgő 2018. Changes in the nest sites of White Stork (Ciconia ciconia) in Hungary. - Ornis Hungarica 26(1): 65-88. DOI: 10.1515/orhu-2018-0005

Abstract The breeding strategies of the White Stork changed drastically during the past decades: a decreasing number of individuals nest on traditional nest sites - trees, roofs, chimneys, whereas electricity poles are increasingly selected. Here we analysed long-term breeding data of White Storks breeding in six Hungarian counties to detect patterns in nest site preferences in Hungary. According to our results, the shift to preference for electricity poles was shown at the same rate in every county, independently from the proportion of original nest sites. After 2000, although electricity poles dominated everywhere, the proportion of nest on poles without platform increased, despite the abundance of available empty platforms. To explain this pattern, we propose that White Storks show a preference for viewpoints, thus choosing to breed as near as possible to optimal habitats, regardless of nest site types. Therefore, conservation measures concerning the nest sites of this species should include preliminary habitat analysis.

Keywords: nest site selection, population dynamics, species conservation, rural area, habitat selection, Hungary

Összefoglalás A fehér gólya fészkelési szokásai látványosan megváltoztak az elmúlt évtizedekben: egyre kevesebb egyed költ hagyományos fészkelöhelyeken - fákon, háztetőkön, kéményeken - és egyre több villanyoszlopokon. Hat megye hosszú távú fészkelési adatsorait elemeztünk annak megválaszolására, hogy Magyarország különböző tájain hogyan zajlott le a fészkelöhely-váltás. Eredményeink alapján mindegyik megyében azonos időben és ütemben kezdődött meg az áttelepülés a villanyoszlopokra, függetlenül a fészekhely-típusok eredeti öszszetételétöl. A 2000-es években már a villanyoszlopok domináltak mindenhol, azonban a tartó nélküli villanyoszlopon fészkelő gólyák aránya nőtt annak ellenére, hogy nagy számban voltak elérhetőek üres fészektartók. Ez azzal magyarázható, hogy a gólyák számára a fészek térbeli elhelyezkedése az elsődleges: a jó táplálkozóterületekhez közelieket preferálják a fészekalap típusától függetlenül. A fehér gólya fészkelésével kapcsolatos természetvédelmi intézkedésekhez, müfészkek helyének optimális kiválasztásához elengedhetetlen az élőhelyek minőségének előzetes felmérése.

Kulcsszavak: fészkelőhely-választás, populációdinamika, fajvédelem, élőhelyválasztás, vidéki térség, habitat-szelekció, Magyarország

${ }^{1}$ Department of Anatomy, Cell- and Developmental Biology, Eötvös Loránd University, 1117 Budapest, Pázmány Péter sétány $1 / C$, Hungary

${ }^{2}$ HNPI-DE Department of Conservation Zoology 4024 Debrecen, Sumen utca 2., Hungary, e-mail: zsolt.vegvari@ gmail.com

*corresponding author 


\section{Introduction}

The White Stork (Ciconia ciconia) originally built nest on trees, but since the extent of natural habitats (wetlands, floodplains, steppes with scattered trees) decreased because of human activities and in parallel, extensive agriculture created alternative habitats, White Storks started to show a preference for nest sites in human settlements. Buildings, as artificial nest sites, facilitated the urbanisation of Storks (Cramp \& Simmons 1977).

The most drastic change of the past decades is represented by a process including White Storks starting to use electricity poles as nest sites as a dominant strategy. Since environmental and sociological changes occurred at different rates in Europe, this transition in nest sites was also spatially uneven. For instance, in Wielkopolska region of Poland, preference for nesting on electricity poles started and predominantly increased in the western areas, in accordance with the direction of rural electrification (Boguczki \& Ożgo 1999). In the former area of Yugoslavia, the dominant nest sites - haystacks - disappeared in a few years due to economical changes. This sudden and compulsory transition impacted the population negatively as breeding success dropped by $50 \%$ during the following decade (Pelle 1999). Further, in Vojvodina region, Serbia, the most abundant nest sites are located on electricity poles (Tucakov 2006). In Estonia, significant amounts of nesting events on electricity poles were registered in 1984, and became dominant in 20 years (Ots 2009). The contribution of electricity poles in nest sites grew sixfold in Bulgaria between 1979 and 1994, in paralleel, the contribution of trees dropped by $50 \%$, possibly because suitable trees disappeared (Petrov et al. 1999). In Turkey, electricity pole was also the most abundant type in the latest census, whereas nest site types were distributed unevenly in regions (Omnuş et al. 2016). For example, in the Kizılirmak delta, tree remained the dominant nest site, attributed to the natural stand of the forests (Yavuz et al. 2012). In Slovenia, nesting on electricity poles appeared in 1965, the proportion of this type is $40 \%$ in 1979 and $80 \%$ since 1999 (Denac 2010). In Portugal, the proportion of nesting on electricity poles increased from $1 \%$ to $25 \%$ between 1984 and 2014, out of this $60 \%$ is the proportion of high voltage poles, which can hold multiple nests (Moreira et al. 2017). In Latvia, the proportion of nesting on electricity poles increased from 1\% to 60\% between 1974 and 2004, mostly without support (Janaus \& Stipniece 2013). In Belarus, Storks nested exclusively on trees and building in 1967, however, nesting on electricity poles increased to $25 \%$ to 2004 , but water towers have the same proportion, which is unusual compared to those of other countries (Samusenko 2013).

The breeding population of Hungary was estimated to $15000-16000$ pairs, based on the first census in 1941, which was calculated considering a larger historical country size (Homonnay 1964). This estimate can be relatively correct as the areas excluded after the peace treaties of WW-II included mainly mountain habitats, unsuitable for Storks. However, according to the partial censuses, only half of this estimated number was likely to be realistic between 1948 and 1951 (Keve 1957). The population decreased further during the 1970s (4900 pairs), since which period it can be considered stable with 4800-5600 pairs (Magyar et al. 1998, Hadarics \& Zalai 2008). According to the Common Bird Monitoring scheme, the population trend is uncertain between 1999 and 2012 (Szép et al. 2012). A likely reason of mortality for half of the known cases can be related to electrocution or collision with 
power lines or electricity poles, with $80 \%$ of the victims being juveniles (Lovászi \& Rékási 2009).

Electricity pole as new nest site indicates both economical and conservation problems: the incidental shortcuts caused by the nest hinders electricity service, and birds - specially fledglings - are threatened by electrocution (Jakab 1991, Jakubiec 1991, Infante \& Peris 2003, Lovászi \& Rékási 2009). At local levels, collision with power lines and poles can contribute significantly to mortality rates (Goriup \& Schulz 1991, Garrido \& Fernandez-Cruz 2003, Galarza \& García 2012), and electromagnetic field can decrease breeding success (Vaitkuviené \& Dagys 2014). Prevention or at least mitigation of these threats is an important task. Possible solutions: lifting up nests with nest supports, establishing nest supports on electricity poles (Goriup \& Schulz 1991, Mužinić \& Cvitan 2001) or setting up independent poles specifically for Storks in potencial habitats (Santopaolo et al. 2013).

Conservation measures aimed at nest sites can bring spectacular results, for example, the Calabrian reintroduction succeeded using artificial platforms (Santopaolo 2013). The White Stork population in Europe is stable again, even increasing in a number of regions (BirdLife 2016). The protection of the species can only be efficient by regarding both the nest site and the habitat needs. There could be areas where habitats would be optimal but inhabitation is impossible due the lack of nest sites, or the other way around.

In this paper, we aimed to answer the following questions:

1. How the proportion of nest sites changed in six Hungarian counties during the last fifty years?

2. What are the primary drivers of shifting to electricity poles?

3. How successful were the conservation actions of the past decades?

\section{Materials and Methods}

The data were retrieved from two resources. First, between 1958-1989, paper forms of White Stork censuses conducted in every five years, published in the archives of Móra Ferenc Múzeum, Szeged. This information includes two types of protocols: postal forms (po) sent out by post offices, filled out by post workers; and more detailed questionnaires (qu) sent out to forestries, hunting companies, schools, filled out by foresters, hunters, teachers, students etc. Second, between 1994-2013, volunteers of BirdLife Hungary provided the data, and this database is now fully available in electronic format, provided by the Hungarian Monitoring Centre. There was only one observation by every method, so the number of White Stork pairs is probably underestimated and there could be also differences in productivity, but these estimates do not differ significantly from real values, as this study states (Aguirre \& Vergara 2009). Nest site types are considered as reliable data, because most of the time nest site can be easily identified and can be surveyed at any time of the breeding season (Boguczki \& Ożgo 1999).

For this study, we chose six out of the 19 Hungarian counties (namely Győr-Moson-Sopron, Somogy, Bács-Kiskun, Békés, Hajdú-Bihar és Szabolcs-Szatmár-Bereg County). We considered the following criteria: 1. data are available from every year 2. there should be 
enough breeding pairs for the analysis 3. they should represent different geographical and socio-economical regions of Hungary. Water permeability of soil types affects the amount of water covered areas which is in relation to the distribution of White Storks, therefore we present the soil types of the counties along with the main water bodies, the typical agricultural use and the human population density (Mezösi 2011, https://www.ksh.hu/).

- Győr-Moson-Sopron (GYMS): soil types: fluviosols, gleysols, phaeozems, chernozems (near rivers), luvisols (Transdanubian Mountains). Main waters: Danube, Rába, Rábca. Agricultural usage: $4.8 \%$ grassland, $53.5 \%$ arable land, $19.2 \%$ forest. Density: $107 / \mathrm{km}^{2}$.

- Somogy: soil types: fluviosols, gleysols, phaeozems (near rivers and lakes), luvisols, arenosols, cambiosols. Main waters: Dráva, lake Balaton. Agricultural usage: 5.2\% grassland, $42.2 \%$ arable land, $29.5 \%$ forest. Density: $52 / \mathrm{km}^{2}$.

- Bács-Kiskun (BK): soil types: regosols, solonchaks, fluviosols (along Danube), chernozems (Bácska region). Main waters: Danube, alkaline, saline lakes. Agricultural usage: $12.3 \%$ grassland, $41.3 \%$ arable land, $20.9 \%$ forest. Density: $61 / \mathrm{km}^{2}$.

- Békés: soil types: chernozems, rendzinas, phaeozems, vertisoils. Main waters: Körös, Berettyó. Agricultural usage: 5.5\% grassland, 67.7\% arable land, 4.6\% forest. Density: 63/ $\mathrm{km}^{2}$.

- Hajdú-Bihar (HB): soil types: chernozems, solonetzes (Közép-Tisza region). Main waters: Tisza, Berettyó, alkaline-saline lakes. Agricultural usage: 17.7\% grassland, $53.1 \%$ arable land, $11.1 \%$ forest. Density: $86 / \mathrm{km}^{2}$.

- Szabolcs-Szatmár-Bereg (SZSZB): soil types: regosols, arenosols; phaeozems, fluviosols (along rivers). Main waters: Tisza. Agricultural usage: 10.8\% grassland, $44.4 \%$ arable land, $21.1 \%$ forest. Density: $94 / \mathrm{km}^{2}$ (Map 1.).

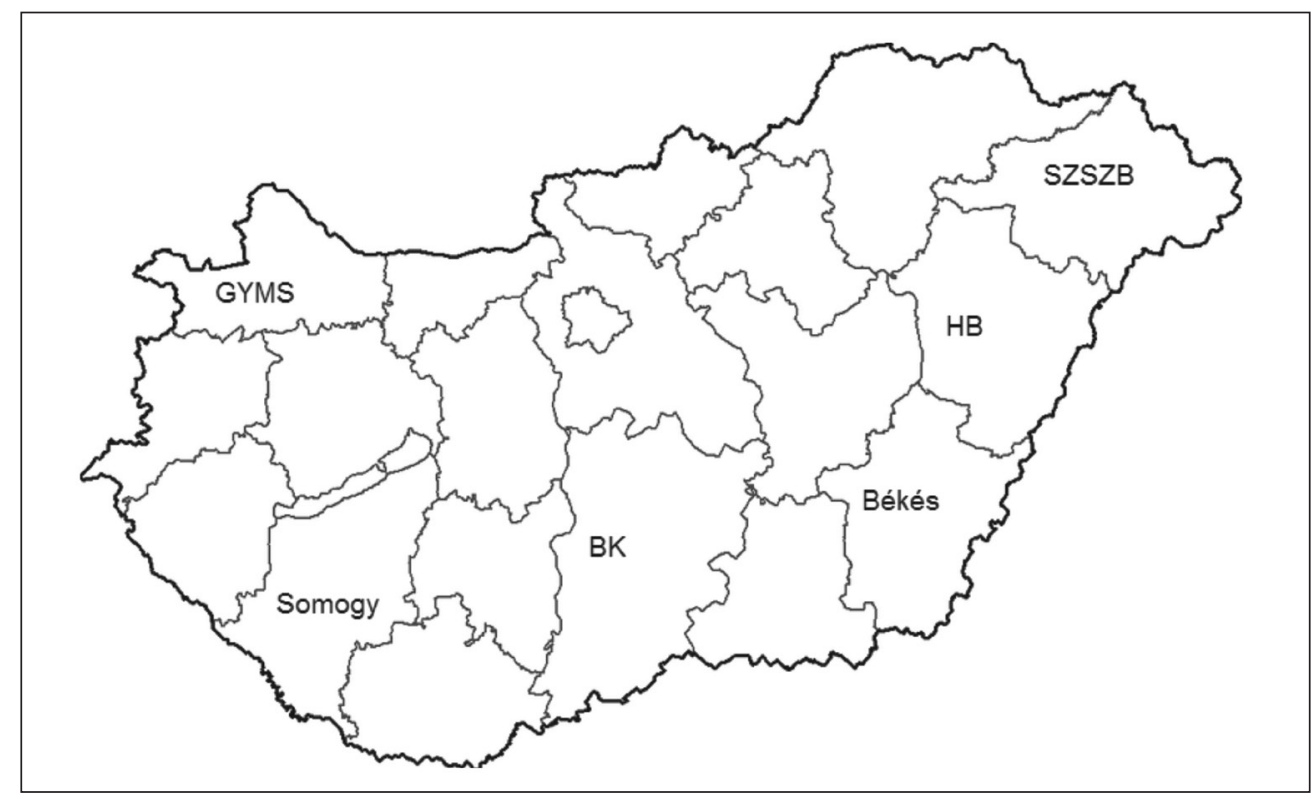

Map 1. Location of the examined counties

1. térkép A vizsgált megyék elhelyezkedése 
We categorised nest sites as follows:

- tree (tr): any species of woody plant, either dead or alive

- building (bu): any type of building, including those of economical usage (barns, pens etc.)

- roof (ro): the covering structure of a building of any material

- chimney (ch): the structure of a building used for ventillation

- electricity pole (ep): pole connected to the power line network without support (ep_ns): electricity pole without nest support with support (ep_s): electricity pole with nest support

- other (ot): independent poles, haystacks, water towers, ruins etc.

Data were filtered and processed with the $\mathrm{R}$ statistical computing software (R Core Team 2015). We summarized the number of nests (both occupied and unoccupied) in every year from the postal forms and the online database to see the overall population changes. We chose the postal forms for the 1958-1989 period because it gives a better estimation, especially for the early years. We applied linear regression to the changes of proportion of nest sites by counties in each data series (namely: the postal forms, the questionnaires and the online data). To investigate overall changes, we used linear mixed model (LMM) implemented in the lme4 R package (Bates et al. 2015). One model contained previous data, where the census type was added as a fixed predictor and the county identity provided the random variable, whereas another model contained the new data, including county identity as random effect term.

Since the new database contains the empty nest supports, the role of equipped nest supports, and hereby the success of nature conservation actions can be measured. We compared the proportion of empty nest supports to electricity poles and the proportion of unoccupied nests to electricity poles (where $100 \%$ was all of the possible nest sites, so all nests + empty nest supports). We applied linear regression for estimating the proportions by counties. For electricity poles with nest supports, we investigated seperately the proportion of empty nest supports and the unoccupied nests.

\section{Results}

\section{Overall population changes based on numbers of nests}

During the span of 10 years of the first three census, the number of Stork nests decreased in every county. The values remained more or less at these values between 1968 and 1984. Between 1994-2013, fluctuations due to insufficient data in the first years affected most counties, but if we take the highest numbers as a basis from this period, we can assume that population increased in every county after 1989 (Table 1).

\section{Changes of nest sites}

Here we show the main characteristics of nest site changes; strengths and direction of trends is indicated more in depth in the tables (Table 2, 3, 4). 


\section{Between 1958-89}

The most profound change was in all counties, in both data sources, the significant increase on nests on electricity poles.

In the beginning, most common nest sites were trees and buildings in Somogy county. Decrease was more drastic and earlier at trees (in both data sources). Questionnaires show that roofs decreased more affected within the building category. Chimneys remained important even in 1989.

Similar to the previous, tree and building nests dominated in Bács-Kiskun in the early years. Despite the decrease, contribution of trees was still high in 1989 (postal forms). Within the building category, roofs decreased more (questionnaires).

Questionnaires show that greatest proportion of nests originally were on chimneys in Békés. In contrast to other counties, of contribution of roofs and trees remained always low.

In Hajdú-Bihar county, the other category emerged as the most important type, which was driven mainly by the contribution of haystacks (based on the notes of postal forms). The proportion of building nests was also high, especially on chimneys.

The majority of nests was found on buildings in Szabolcs-Szatmár-Bereg counties. The contribution of roofs was a bit higher than in other counties. In case of tree nests, fluctuation was strong in postal forms.

Based on the linear mixed model, the trends of the two data sources differed significantly in the case of other category: the postal forms showed a greater decrease. The difference between the six counties was the lowest at the electricity poles: $4.5 \%$ of variance was explained by the county as random variable. This contribution of variance was $47.6 \%$ at the trees, $45.9 \%$ at the buildings and $17.4 \%$ at the other category (Table 5 ).

\section{Between 1994-2013}

The most striking change was the increase of the proportion of nests on electricity poles without supports in all counties and was significant in 5 out of 6 cases. In parallel, the proportion of nests on electricity poles with support decreased in 5 out of 6 cases. Altogether, this nest site still remained dominant in every county (Table 6, 7).

In Györ-Moson-Sopron, the contribution of chimney and other category was $10-15 \%$. Significant decrease was observed in case of the trees.

The overall proportion of nests on electricity poles significantly decreased in Somogy. The proportion of nests on chimneys and other sites amounted to $5-10 \%$. No nest on roof was reported.

The only significant change in Bács-Kiskun was detected in the decrease of nests on roofs. The proportion of chimney nests was around $10-20 \%$. The contribution of other category was $5-10 \%$. No nest on trees was reported.

The overall proportion of nests on electricity poles significantly increased in Békés. There was a significant decrease in case of chimneys, although their contribution is still high (20$25 \%$ ). There was a significant increase in case of roofs.

The contribution of chimney nests was around $5-10 \%$ in Hajdú-Bihar. There was a significant increase in case of tree nests. 
The overall proportion of nests on electricity poles significantly decreased in Szabolcs-Szatmár-Bereg. The proportion of other category was higher due to the independent poles $(20-10 \%)$, but also significantly decreased.

Based on the linear mixed model, the proportion of nests on electricity poles with support decreased significantly overall and $18.9 \%$ of the variance is explained by the differences between counties. There was a significant increase in case of electricity poles without support, $9-14.9 \%$ of variance provided by county identity as random factor. There was a significant decrease in case of the roofs (variance contribution of countries: 51.8\%). A positive trend was observed in case of the chimney and tree category (variance contribution of counties respectively: $41.6 \%$ and $17.6 \%$ ). A negative trend was observed at the other category (variance contribution of counties: $26.7 \%$ ) (Table 8).

The proportion of empty nest supports on electricity poles significantly increased in BácsKiskun, Hajdú-Bihar, Somogy és Szabolcs-Szatmár-Bereg. The proportion of unoccupied nests on electricity poles with support significantly increased in Somogy (Table 9).

\section{Discussion}

The White Stork population in Europe drastically decreased between 1970 and 1990, which is hypothesised to be the result of decreasing of suitable habitats and nest sites, increasing mortality resultes by power lines, drought in the wintering areas, chemical crop control and the interactions among these effects (Goriup \& Schulz 1991, Jakubiec 1991, Kanyamibwa et al. 1993, Schulz 1994). The population size reached its lowest number in 1984 with 135000 pairs and started to increase in the following decades (Thomsen \& Hötker 2006). The population in Europe is now estimated to 224000-247000 pairs (BirdLife International 2016). The reasons of increase - between conservation actions - is attributed to the expansion of area to the north (Ots 2009), the occupation of habitats at higher altitudes (Tryjanowski et al. 2005b), the reoccupation to original breeding areas (Santopaolo 2013) and locally the advantageous changes in agriculture (Forgách 1997, Vaitkuviene \& Dagys 2015). During the past decades, Storks fed also in rubbish dumps, which allows their permanent colonization in suboptimal habitats (Kruszyk \& Ciach 2010), or even allowing wintering in the region (Tortosa et al. 2002, Gilbert et al. 2016).

The original proportion of the nest sites depended on traditional agricultural technology of the given county. While specialty of Somogy was represented by the woodland pastures, in Bács-Kiskun it was exemplified by loosely connected network of farms. In Győr-Moson-Sopron, Hajdú-Bihar és Szabolcs-Szatmár-Bereg, storks mainly nested on agricultural buildings inside villages. In Hajdú-Bihar county, the high proportion of nest on haystacks shows the significant use of meadows for mowing: $22-26 \%$ of nest was built on haystacks in 1941 (Homonnay 1964), but even in 1963, this category dominated over all the others. In Békés, extended arable lands was typical, which Storks avoid, since these habitats are suboptimal for them (Denac 2006a), that is why the amount of nest was relatively low. These nests were mainly built on chimneys, inside villages. 
The changes connected with building practices have been reported worldwide (Goriup $\&$ Schulz 1991) and are also well-documented in written resources of Hungarian White Stork conservation (Jakab 1991). The proportion of nests on roofs decreased in a White Stork population in Poland, because the agricultural buildings with thatched roofs preferred by Storks disappeared with the modernisation of agriculture (Daniluk et al. 2006, Kosicki 2006). These types of buildings were often classified into the „other” categories in the postal forms, so the proportion of nests on roofs could be underestimated. Thatched roofs are more suitable for Storks than harder roof types from where the nest may easily fall down. However, human preferences are directed towards ceramic tiles and slate roofs, as these require less maintenance and are also more fireproof.

The proportion of nests on chimneys also decreased in almost every county. Based on the notes, the main reason of this is the modified shape of chimneys: the newer types are more slender and opened on the top in contrast with the sturdier ones, with holes on the sides. Sometimes the top is cone-shaped, especially aiming to deter storks.

According to the 1941 census, a certain proportion of the population - in all counties nested outside the villages, near to small farms, almost exclusively on trees (Homonnay 1964). The possible reason is that the vicinity of these farms was especially rich in optimal habitats, to which storks tried to nest as close as possible (Ożgo \& Boguczki 1999). We assume they preferred trees because suitable old trees were more abundant and also - based on the additional notes - because people did not tolerate the Storks on the buildings. This stable pattern was not present in our analysis because of the settlement pattern and agricultural changes. Where the changes occurred later - Bács-Kiskun in our case - the proportion of nests remained high.

In contrast to previous nest sites, it is improbable that the availability of trees drastically decreased for nesting. We did not find records of mass tree logging, although it is true that in primarily open areas, disappearance of even small number of trees can have a substantial impact on Storks. Grasslands without trees, even if considered as optimal habitats, are not occupied by Storks if travel costs from nearest possible nest site are larger than the energy gain of the habitat (Jakab 1989, Olsson \& Arvid 2014).

The examined counties showed great differences in the availability and usage of traditional nest sites, in contrast, the shift to nesting on electricity poles happened almost synchronously everywhere. Thus, it is improbable that the disappearance of other nest site was the primary reason of this change. Since the population was already decreasing in the analysed period, it was not caused by the changes in nest sites. The structure of population has changed.

In Hungary, electricity was introduced to the last village in 1963 (http://mtva.hu/hu/sajto-es-fotoarchivum/5654-50-eve-fejezodoett-be-magyarorszagon-a-falvak-villamositasa), but electricity poles were used by Storks only occupied in larger amounts from 1968. At that time, the distribution of electricity poles was already equal everywhere, so the swift indeed happened independently from rural electrification. In certain regions of Poland, Storks also started to nest on electricity poles much later after they became abundant (Tryjanowski et al. 2009, Janiszewski et al. 2015). But in Wielkopolska region, differences in nest site choice remained between the earlier and later electrified western and eastern parts 
(Boguczki \& Ożgo 1999). Regional differences were also observed in the population of Olt river basin: the proportion of nests on electricity poles is still the highest in the N-NW part where electrification started and the first nest on this nest site was reported in the 1960s (Kósa et al. 2002).

The time of electrification explains the differences in patterns of nest site usage, but not the cause of why did electricity poles became attractive for Storks. A possible assumption is that Storks that nest on electricity poles have a higher productivity. In a study in Poland, no differences were found between nest site types neither in the number of fledged young nor in the proportion of occupied nests. However, in the case of electricity poles, productivity was affected by nest support: mean number of chicks was lower as the mean of all nest sites after the year the support was equipped, but significantly higher in the second year. Disturbance of the nest is unfavourable for the chicks for short terms, but in the long run, chicks are safer in nest with supports (Tryjanowski 2009). Based on a study in northern Hungary, productivity was significantly lower in nests on unsupported electricity poles. This could stem primarily from the fact that young and unexperienced individuals nest on these poles (Boldogh 2009). However, this could indicate preference indirectly, because earlier individuals occupy other nest sites sooner. In a former study on the same area, earliest, most experienced individuals occupy nests on chimneys first (Boldogh 1998), so higher productivity on this type is more affected by the age of Storks, not directly the nest site type.

Another assumption for the advantage of electricity poles is lower predation rates as well as human disturbance. The productivity of Storks on trees presumably decreased because of predators in Poland (Tryjanowski 2009). The role of the conflicts between Storks and humans in nest site selection was not examined as far as we know, possibly due to difficulties in sampling data.

Realising the increasing role of electricity poles, Hungarian Birdlife started to put on nest supports in cooperation with the electricity companies in the 1970s. From 1980, 3000 nest supports were equipped either under existing nests or to empty electricity poles or independent poles (Lovászi 2004). Further 650 nest supports were placed in the 1990s, 2000 between 2001-2002 and at least 1000 after that (Horváth et al. 2010).

In the 1990s, when the population was increasing, Storks started to occupy the empty nest supports, available in great abundance. At the turn of the millenium, most new nest were built on electricity poles with nest support. Out of the traditional nest sites, only the proportion of nest on chimneys remained significant, although to a different degree between counties.

As the density of population increased, it proved to be a general trend that out of nests on electricity poles, the proportion of nests with supports decreased and the ones without support increased, although empty nest supports were still available in high numbers. The proportion of empty nest supports (on electricity poles) increased in every county. This can be explained the same was as experienced in a study in Middle Poland, where it was found that nesting on electricity poles expanded fastest in the best habitats.

It becomes harder for the newcoming individuals to fit in the high density population, because they have to choose a nest site that is close to the feeding areas but not too close to the other pairs. The number of chicks is positively correlated with the distance of neighbors 
in optimal habitats (Nowakowski \& Wasilewka 2006) and negatively correlated with the number of neighbors in suboptimal habitats, which is caused by strong intraspecific competition (Denac 2006b). The spatial situation of the nest has priority: the Storks began to use the electricity poles in large amounts because they easily found suitable ones due to the big coverage (Janiszewski et al. 2015). In an analogous way, an electricity poles with good situation but without nest support is a better choice than one in a bad place with nest support. The expanding White Stork population in western France started to nest mainly on trees, despite the mass presence of artificial nest platforms (Gadenne et al. 2014). The same was experienced in western Poland: first breeders built their nest more often to trees and unusual places, near to feeding areas (Tobolka et al. 2013).

The possible substitute for electricity pole is the independent pole erected specifically for Storks. The distraction of Storks from electricity poles with setting of independent poles was successful in Slovakia, where $25.1 \%$ and $37 \%$ was the respective proportion of these types in 1995, whereas contribution of electricity poles was 38\% at the 1984 census (Fulín 1999). In Karkov region, Ukraine, the proportion of electicity pole nests was relatively high (18\%) even in 1974 and increasing, possibly due the lack of alternative nest sites in the steppe, but now half of the population breeds on poles made specifically for them (Atemasova et al. 2016). However, they are not necessarily suitable for substitution of existing nests: in a German population, after nests from electricity poles were removed, independent poles were offered next to them directly, yet Storks rejected the new poles, so nest supports solved the problem (Köhler 1999). These pole types began to set up in larger numbers from 1989 in Hungary: in the 1994-2013 database, independent poles constitute almost exclusively the "other" nest site category, so it is easy to follow the trend. After the initial upturn, the proportion of nests on independent poles decreased like at the electricity poles. This is especially apparent in Szabolcs-Szatmár-Bereg, where there is a big amount of these poles. We can assume the same as with the electricity poles: after the nest sites with the best location were occupied, the remaining ones did not become more attractive compared to another possible nest sites. In Calabria, Italy, recolonization of White Stork was successfully facilitated with independent poles, the population grew threefold from 2007 to 2012. But the study underlined that it is important to keep distance between the poles, because competition arises within neighbor pairs too close $(<600 \mathrm{~m})$ to each other (Santopaolo 2013). This distance is not standard, however, since the quality of habitat affects the size of the territory (Ożgo \& Boguczki 1999) and so the density of pairs. Storks still breed colonially in areas with high carrying capacity, for example in Spain (Vergara \& Aguirre 2006), in Poland (Tryjanowski et al. 2005a) or in Nagyiván next to Hortobágy National Park, Hungary (golya.mme.hu).

Therefore, placement of nest supports and/or indepentent poles can truly be efficient only with the consideration of the habitat needs: it worth setting these tools up where reliable models confirm that the expected number of fledglings is high enough to sustain or even increase the population (Olsson \& Arvid 2014). Beside that it is also important to protect and/ or maintain the old, big nests, because those are occupied more often (Tryjanowski 2005b) and productivity is higher at those nests (Vergara 2010). White Stork is a good indicator of biodiversity, so by protection of this species, we also help the case of biodiversity of habitats (Latus et al. 2000) and farmland birds (Kosicki 2007, Tobolka et al. 2012). 


\section{Acknowledgements}

This paper would not have been possible without the help and support of generous people. Hereby we would like to thank Károly Nagy, the head of the BirdLife Hungary Monitoring Center, for providing data and giving insight; Péter Lovászi, the White Stork protection program leader, for giving additional information; the colleagues of Móra Ferenc Museum, András Varga, László Tóth, Gábor Csehó and Béláné Vécsei for providing data; and all the anonymous volunteers for taking their time to contribute to the surveys.

\section{References}

Aguirre, J. I. \& Vergara, P. 2009. Census methods for White stork (Ciconia ciconia): bias in sampling effort related to the frequency and date of nest visits. - Journal of Ornithology 150(1): 147-153. DOI: 10.1007/s10336008-0329-3

Atemasova, T. A., Atemasov, A. A. \& Brusentsova, N. A. 2016. White Stork at the Northern-East of Ukraine: trends in population dynamic at the edge of range. - In: Jerzak, L., Shephard, J., Aguirre, J. I., ShamounBaranes, J. \& Tryjanowski, P. (eds.) The White Stork: studies in biology, ecology and conservation. - Oficina Wydawnicza Universytetu Zielonogórskiego, Zielona Góra, pp. 63-71.

Bates, D., Maechler, M., Bolker, B. \& Walker S. 2015. Fitting linear mixed-effects models using lme4. - Journal of Statistical Software 67(1): 1-48. DOI: 10.18637/jss.v067.i01

BirdLife International 2004. Birds in Europe: population estimates, trends and conservation status. - Cambridge, UK: Birdlife International, Birdlife Conservation Series, No.12. p. 47.

BirdLife International 2016. Species factsheet: Ciconia ciconia (2015) European Red List Assessment. - http:// datazone.birdlife.org/userfiles/file/Species/erlob/supplementarypdfs/22697691_ciconia_ciconia.pdf

Boguczki, Z. \& Ożgo, M. 1999. Changes in the nest site selection of the White Stork Ciconia ciconia in Wielkopolska (Western Poland) over the period 1974-1994. - In: Schulz, H. (ed.) Weissstorch im Aufwind? - White Storks on the up? - Proceedings of the International Symposium on the White Stork, Hamburg 1996. NABU, Bonn, pp. 437-442.

Boldogh, S. A. 2009. Védett gerincesek konzervációbiológiája - monitoring és fajmegőrzési programok tervezése és kivitelezése [Conservation biology of protected vertebrates - planning and implementation of conservation and monitoring programmes]. - Debreceni Egyetem Természettudományi Doktori Tanács, Juhász-Nagy Pál Doktori Iskola, pp. 51-65.

Boldogh, S. 1998. A fehér gólya (Ciconia ciconia) hatékony védelmét megalapozó vizsgálatok tapasztalatai Borsod-Abaúj-Zemplén megyében [Studies for the effective protection of the White Stork (Ciconia ciconia) in Borsod-Abaúj-Zemplén County, NE Hungary]. - Ornis Hungarica 8(Suppl.1): 133-136.

Cramp, S. \& Simmons, K. E. L. 1977. White Stork. - In: Cramp S., Simmons K. E. L. (eds.) Handbook of the Birds of the Western Palearctic, Vol. 1. - Oxford University Press, Oxford, pp. 328-335.

Daniluk, J., Korbal-Daniluk, A. \& Mitrus, C. 2006. Changes in population size, breeding success and nest location of a local White Stork Ciconia ciconia population in Eastern Poland. - In: Tryjanowski, P., Sparks, T. H. \& Jerzak, L. (eds.) The White Stork in Poland: studies in biology, ecology and conservation. - Bogucki Wydawnictwo Naukowe, Poznań, pp. 15-21.

Denac, D. 2006a Resourse-dependent weather effect in the reproduction of the White Stork Ciconia ciconia. Ardea 94(2): 233-240.

Denac, D. 2006b Intraspecific exploitation competition as cause for density dependent breeding success in the White Stork. - Waterbirds 29: 391-394.

Denac, D. 2010. Population dynamics of the White Stork Ciconia ciconia in Slovenia between 1999 and 2010. Acrocephalus 31(145/146): 101-114. DOI: 10.2478/v10100-010-0007-4

Forgách, B. 1997. A fehér gólya (Ciconia c. ciconia L.) állományának helyzete Békés megyében [The situation of the White Stork population in Békés County]. - A Puszta 14: 133-138. (in Hungarian)

Fulín, M. 1999. The White Stork in Slovakia in 1994 and 1995. - In: Schulz, H. (ed.) Weissstorch im Aufwind? White Storks on the up? - Proceedings of the International Symposium on the White Stork, Hamburg 1996. NABU, Bonn, pp. 437-442. 
Gadenne, H., Cornulier, T., Eraud, C., Barbraud, J. C. \& Barbraud, C. 2014. Evidence for density-dependent habitat occupancy at varying scales in an expanding bird population. - Population Ecology 56(3): 493-506. DOI: 10.1007/s10144-014-0435-4

Galarza, A. \& García, I. 2012. Restocking White Stork Ciconia ciconia (L., 1758) population in Biscay: reintroduction in the Urdaibai Biosphere Reserve. - Munibe Ciencias Naturales 60: 191-200.

Garrido, J. R. \& Fernandez-Cruz, M. 2003. Effects of power lines on a White Stork Ciconia ciconia population in central Spain. - Ardeola 50: 191-200.

Goriup, P. D. \& Schulz, H. 1991. Conservation management of the White Stork. - In: Salathé, T. (ed.) Conserving Migratory Birds. - ICBP Techn. Publ. 12, Cambridge, pp. 97-127.

Gilbert, N. I., Correia, R. A., Silva, J. P., Pacheco, C., Catry, I., Atkinson, P. W., Gill, J. A. \& Franco, A. M. A. 2016. Are White Storks addicted to junk food? Impacts of landfill use on the movement and behaviour of resident White Storks (Ciconia ciconia) from a partially migratory population. - Movement Ecology 4:7. DOI: 10.1186/s40462-016-0070-0

Hadarics, T. \& Zalai, T. 2008. Nomenclator Avium Hungariae - An annonated list of the birds of Hungary. - MME Birdlife Hungary, Budapest, p. 78. (in Hungarian and English)

Homonnay, N. 1964. Magyarország és környező területei gólyaállományának mennyiségi felvételezése az 1941. évben [Quantitative census of the White Stork population of Hungary and neighboring areas in 1941]. Aquila 69/70: 83-102. (in Hungarian and German)

Horváth, M., Demeter, I., Bagyura, J., Kovács, A., Lovászi, P., Nagy, K., Szügyi, K. \& Tóth, P. 2010. Madarak és légvezetékek [Birds and overhead power lines]. - Magyar Madártani és Természetvédelmi Egyesület, Budapest, p. 25. (in Hungarian)

Infante, O. \& Peris, S. 2003. Bird nesting on electric power supports in northwestern Spain. - Ecological Engineering 20: 321-326. DOI: 10.1016/S0925-8574(03)00013-2

Jakab, B. 1989. A talajtípusok szerepe a fehér gólya (Ciconia ciconia) elterjedésében Magyarországon [The role of soil types in the distribution of White Stork in Hungary]. - A Móra Ferenc Múzeum Évkönyve 1989-90(1): 519-531. (in Hungarian and German)

Jakab, B. 1991. A hazai madárbarát villamosművek szerepe a fehér gólya állományának alakulásában [The role of the bird friendly electric power industry in forming the White Stork population in Hungary]. - In: Király, Á. \& Gazda, I. (eds.) Gólyavédelem a villamoshálózatokon [White Stork protection on electricity networks]. - A Magyar Tudománytörténeti Intézet Tudományos Közleményei 79., Magyar Elektrotechnikai Múzeum, Budapest, pp. 9-14. (in Hungarian)

Jakubiec, Z. 1991. Causes of breeding losses and adult mortality in White Stork Ciconia ciconia (L.) in Poland. - Studia Nature 37: 107-124.

Janaus, M. \& Stipniece, A. 2013. The White Stork in Latvia from 1934 to 2005. - In: NABU. White Stork populations across the world - Results of the $6^{\text {th }}$ International White Stork Census 2004/05., Berlin (Imprint)

Janiszewski, T., Minias, P. \& Wojciechowski, Z. 2015. Selective forces responsible for transition to nesting on electricity poles in the White Stork Ciconia ciconia. - Ardea 103: 39-50. DOI: 10.5253/arde.v103i1.a4

Kanyamibwa, S., Bairlein, F. \& Schierer, A. 1993. Comparison of survival rates between populations of the White Stork Ciconia ciconia in Central Europe. - Ornis Scandinavica 24: 297-302. DOI: 10.2307/3676791

Keve, A. 1957. White-Stork-Census in Hungary in the years 1948 and 1949. - Aquila 63-64: 211-225.

Kósa, F., Demeter, L., Papp, T., Philippi, F., Lutsch, H-J. \& György, K. 2002. Distribution, population size and dynamics of the White Stork (Ciconia ciconia L.) in the upper and middle Olt river basin. - Tiscia Monograph Series 6: 205-233.

Kosicki, J. Z. \& Kuźniak, S. 2006. Long-term population size and productivity dinamics of a local White Stork Ciconia ciconia population in Wielkopolska. - In: Tryjanowski, P., Sparks, T. H. \& Jerzak, L. (eds.) The White Stork in Poland: studies in biology, ecology and conservation. - Bogucki Wydawnictwo Naukowe, Poznań, pp. 23-33.

Kosicki, J. Z., Sparks, T. H. \& Tryjanowski, P. 2007. House Sparrows benefit from the conversation of White Storks. - Naturwissenschaften 94: 412-415. DOI: 10.1007/s00114-006-0207-x

Köhler, W. 1999. Bestandsentwicklung des Weißstorches in der Niederlausitz/Deutschland und Verluste an Freileitungen in Ostdeutschland [Population development of the White Stork in Niederlausitz/Germany and deaths caused by overhead lines in eastern Germany]. - In: Schulz, H. (ed.) Weissstorch im Aufwind? - White Storks on the up? - Proceedings of the International Symposium on the White Stork, Hamburg 1996. NABU, Bonn, pp. 437-442. (in German) 
Kruszyk, R., Ciach, M. 2010. White Storks, Ciconia ciconia, forage on rubbish dumps in Poland - a novel behaviour in population. - European Journal of Wildlife Research 56: 83-87. DOI: 10.1007/s10344-009-0313-0

Latus, C., Kujawa, K., Glemnitz, M. \& Nauk, P. A. 2000. The influence of landscape structure on White Stork's Ciconia ciconia nest distribution. - Acta Ornithologica 35: 97-102.

Lovászi, P. \& Rékási, J. 2009. A fehér gólya [White Stork]. - In: Csörgő, T., Karcza, Zs., Halmos, G., Magyar, G., Gyurácz, J., Szép, T., Bankovics, A., Schmidt, A. \& Schmidt, E. (eds.) Magyar Madárvonulási Atlasz [Hungarian Bird Migration Atlas]. - Kossuth Kiadó Zrt., Budapest, pp. 186-192.

Lovászi, P. 2004. A fehér gólya (Ciconia ciconia) helyzete Magyarországon az 1941-2002 között [Status of the White Stork (Ciconia ciconia) in Hungary between 1941 and 2002]. - Aquila 111: 11-18. (in Hungarian with English Summary)

Magyar, G., Hadarics, T., Waliczky, Z., Schmidt, A., Nagy, T. \& Bankovics, A. 1998. Nomenclator Avium Hungariae. Magyarország madarainak névjegyzéke [An Annotated List of the Birds of Hungary]. - KTM Természetvédelmi Hivatal Madártani Intézete - Magyar Madártani és Természetvédelmi Egyesület - Winter Fair, Budapest-Szeged, p. 32. (in Hungarian and English)

Mezősi, G. 2011. Magyarország természetföldrajza [Geography of Hungary]. - Akadémiai Kiadó, Budapest (in Hungarian)

Moreira, F., Encarnação, V., Rosa, G., Gilbert, N., Infante, S., Costa, J., D’Amico, M., Martins, R. C. \& Catry, I. 2017. Wired: impacts of increasing power line use by a growing bird population. - Environmental Research Letters 12: 024019. DOI: 10.1088/1748-9326/aa5c74

Mužinić, J. \& Cvitan, I. 2001. Choice of nest platform material for the White Stork (Ciconia ciconia). - Israel Journal of Zoology 47: 167-171.

Nowakowski, J. J. \& Wasilewska, B. 2006. The relationship between spatial distribution, intrapopulation competition and the reproduction parameters of White Stork Ciconia ciconia in the southern basin of the Biebrza River during the years 1994-1999. - In: Tryjanowski, P., Sparks, T. H. \& Jerzak, L. (eds.) The White Stork in Poland: studies in biology, ecology and conservation. - Bogucki Wydawnictwo Naukowe, Poznań, pp. 99-113.

Olsson, O. \& Arvid, B. 2014. A model for habitat selection and species distribution derived from central place foraging theory. - Oecologia 175(2): 537-548. DOI: 10.1007/s00442-014-2931-9

Omnuş, O., Bolat, Ü., Usta, T., Siki, M. \& Altun, C. 2016. Filling the largest gap of the White Stork (Ciconia ciconia) population in the Western Palearctic region: the results of the first complete countrywide White Stork census in Turkey. - In: Jerzak, L., Shephard, J., Aguirre, J. I., Shamoun-Baranes, J. \& Tryjanowski, P. (eds.) The White Stork: studies in biology, ecology and conservation. - Oficina Wydawnicza Universytetu Zielonogórskiego, Zielona Góra, pp. 63-71.

Ots, M. 2009. The White Stork (Ciconia ciconia) in Estonia till year 2008. - Hirundo 22: 32-42.

Ożgo, M. \& Boguczki, Z. 1999. Home range and intersexual differences in foraging habitat use of a White Stork (Ciconia ciconia) breeding pair. - In: Schulz, H. (ed.) Weissstorch im Aufwind? - White Storks on the up? - Proceedings of the International Symposium on the White Stork, Hamburg 1996. NABU, Bonn, pp. 437-442.

Pelle, Z. 1999. Status and biology of the White Stork in Yugoslavia. - In: Schulz, H. (ed.) White Storks on the up? - Proceedings of the International Symposium on the White Stork, Hamburg 1996. NABU, Bonn, pp. 219-221.

Petrov, T., Iankov, P. \& Georgiev, D. 1999. Population status of the White Stork (Ciconia ciconia) in Bulgaria in the years 1994/95. - In: Schulz, H. (ed.) Weissstorch im Aufwind? - White Storks on the up? - Proceedings of the International Symposium on the White Stork, Hamburg 1996. NABU, Bonn, pp. 241-247.

R Core Team 2015. R: A language and environment for statistical computing. - R Foundation for Statistical Computing, Vienna, Austria, https://www.R-project.org/

Samusenko, I. 2013. The breeding population of the White Stork in Belarus in 2004-2005. - In: NABU 2013. White Stork populations across the world. - Results of the $6^{\text {th }}$ International White Stork Census 2004/05., Berlin

Schulz, H. 1994. The White Stork Ciconia ciconia - In: Tucker, G. M. \& Heath, M. F. (eds.) Birds in Europe and their conservation status. - BirdLife Conservation Series 3. BirdLife International, Cambridge, U.K., pp. $100-101$.

Santopaolo, R., Godino, G., Golia, S., Mancuso, A., Monterosso, G., Pucci, M., Santopaolo, F. \& Gustin, M. 2013. Increase of White Stork Ciconia ciconia population attracted by artificial nesting platforms. - Conservation Evidence 10: 67-69. 
Szép, T., Nagy, K., Nagy, Zs. \& Halmos, G. 2012. Population trends of common breeding and wintering birds in Hungary, decline of long-distance migrant and farmland birds during 1999-2012. - Ornis Hungarica 20(2): 13-63. DOI: 10.2478/orho-2013-0007

Thomsen, K. \& Hötker, H. 2006. The $6^{\text {th }}$ International White Stork Census: 2004-2005. - In: Boere, G. C., Galbraith, C. A. \& Sroud, D. A. (eds.) Waterbirds around the World. - The Stationery Office, Edinburgh, pp. 493-495.

Tobolka, M., Sparks, T. H. \& Tryjanowski, P. 2012. Does the White Stork Ciconia ciconia reflect farmland bird diversity? - Ornis Fennica 89: 222-228.

Tobolka, M., Kúzniak, S., Zolnierowicz, K., Sparks, T. H. \& Tryjanowski, P. 2013. New is not always better: low breeding success and different occupancy pattern in newly built nests of a long-lived species, the White Stork Ciconia ciconia. - Bird Study 60: 399-403. DOI: 10.1080/00063657.2013.818934

Tortosa, F. S., Caballero, J. M. \& Reyes-Lopez, J. 2002. Effect of rubbish dumps on breeding success in the White Stork in southern Spain. - Waterbirds 25: 39-43. DOI: 10.1675/1524-4695(2002)025[0039:EORDOB]2.0. $\mathrm{CO} ; 2$

Tryjanowski, P., Jerzak, L. \& Radkiewicz, J. 2005a Effect of water level and livestock on the productivity and numbers of breeding White Storks. - Waterbirds 28: 378-382. DOI: 10.1675/1524-4695(2005)028[0378:EOWLAL]2.0.CO;2

Tryjanowski, P., Sparks, T. H. \& Profus, P. 2005b Uphill shifts in the distribution of the White Stork Ciconia ciconia in southern Poland: the importance of nest quality. - Diversity and Distributions 11: 219-223. DOI: 10.1111/j.1366-9516.2005.00140.x

Tryjanowski, P., Kosicki, J. Z., Kuźniak, S. \& Sparks, T. H. 2009. Long-term changes and breeding success in relation to nesting structures used by the White Stork Ciconia ciconia. - Annales Zoologici Fennici 46: 34-38. DOI: $10.5735 / 086.046 .0104$

Tucakov, M. 2006. Population development, nest site selection and conservation measures for White Stork Ciconia ciconia along the lower Tamiš River (Vojvodina, N Serbia). - Acrocephalus 27: 13-20.

Vergara, P. \& Aguirre, I. J. 2006. Age and breeding success related to nest position in a White Stork Ciconia ciconia colony. - Acta Oecologica 30: 414-418. DOI: 10.1016/j.actao.2006.05.008

Vergara, P., Gordo, O. \& Aguirre, J. I. 2010. Nest size, nest building behaviour and breeding success in a species with nest reuse: The White Stork Ciconia ciconia. - Annales Zoologici Fennici 47(3): 184-194. DOI: $10.5735 / 086.047 .0303$

Vaitkuviené, D. \& Dagys, M. 2014. Possible effects of electromagnetic field on White Storks Ciconia ciconia breeding on low-voltage electricity line poles. - Zoology and Ecology 24(4): 289-296. DOI: $10.1080 / 21658005.2014 .962783$

Vaitkuvienè, D. \& Dagys, M. 2015. Two-fold increase in White Stork (Ciconia ciconia) population in Lithuania: a consequence of changing agriculture? - Turkish Journal of Zoology 39: 144-152. DOI: 10.3906/zoo-1402-44

Yavuz, K. E., Yavuz, N., Tavares, J. \& Barış, Y. S. 2012. Nesting habits and breeding success of the White Stork, Ciconia ciconia, in the Kiz1lirmak delta, Turkey. - Zoology in the Middle East 57: 19-26. DOI: $10.1080 / 09397140.2012 .10648959$ 
Table 1. Number of nest by counties in every year 1. táblázat $\mathrm{A}$ fészkek száma megyénként és évenként

\begin{tabular}{|c|c|c|c|c|c|c|c|c|c|c|c|c|}
\hline & 1958 & 1963 & 1968 & 1974 & 1979 & 1984 & 1989 & 1994 & 1999 & 2000 & 2001 & 2002 \\
\hline GYMS & 277 & 202 & 148 & 139 & 130 & 146 & 107 & 109 & 141 & 4 & 157 & 1 \\
\hline Somogy & 586 & 515 & 306 & 263 & 225 & 235 & 177 & 84 & 106 & 9 & 7 & 7 \\
\hline BK & 530 & 409 & 271 & 262 & 179 & 256 & 150 & 16 & 38 & 6 & 66 & 3 \\
\hline Békés & 319 & 202 & 218 & 182 & 196 & 199 & 154 & 0 & 0 & 0 & 2 & 253 \\
\hline $\mathrm{HB}$ & 1010 & 795 & 466 & 481 & 495 & 402 & 350 & 0 & 261 & 0 & 2 & 243 \\
\hline SZSZB & 1026 & 723 & 461 & 424 & 447 & 421 & 349 & 301 & 353 & 218 & 263 & 405 \\
\hline & 2003 & 2004 & 2005 & 2006 & 2007 & 2008 & 2009 & 2010 & 2011 & 2012 & 2013 & \\
\hline GYMS & 21 & 256 & 181 & 177 & 33 & 22 & 183 & 183 & 181 & 182 & 171 & \\
\hline Somogy & 154 & 307 & 283 & 298 & 302 & 121 & 139 & 106 & 103 & 119 & 75 & \\
\hline BK & 57 & 241 & 92 & 46 & 127 & 51 & 131 & 92 & 202 & 194 & 149 & \\
\hline Békés & 32 & 119 & 81 & 278 & 370 & 375 & 387 & 403 & 403 & 423 & 417 & \\
\hline $\mathrm{HB}$ & 195 & 225 & 251 & 610 & 471 & 134 & 722 & 581 & 434 & 286 & 140 & \\
\hline SZSZB & 485 & 625 & 535 & 571 & 535 & 578 & 588 & 529 & 385 & 535 & 610 & \\
\hline
\end{tabular}

Table 2. Proportions of nest sites by counties in the 1958-1989 period, based on postal forms 2. táblázat A fészekalapok arányai megyénként az 1958-1989-es periódusban, a postai adatlapok alapján

\begin{tabular}{|l|c|c|c|c|c|c|c|}
\hline \multicolumn{1}{|c|}{ GYMS } & $\mathbf{1 9 5 8}$ & $\mathbf{1 9 6 3}$ & $\mathbf{1 9 6 8}$ & $\mathbf{1 9 7 4}$ & $\mathbf{1 9 7 9}$ & $\mathbf{1 9 8 4}$ & $\mathbf{1 9 8 9}$ \\
\hline ep & 0.00 & 0.01 & 0.02 & 0.08 & 0.28 & 0.45 & 0.60 \\
\hline tr & 0.13 & 0.11 & 0.05 & 0.11 & 0.07 & 0.04 & 0.00 \\
\hline bu & 0.79 & 0.83 & 0.87 & 0.76 & 0.62 & 0.49 & 0.36 \\
\hline ot & 0.08 & 0.06 & 0.05 & 0.04 & 0.04 & 0.02 & 0.04 \\
\hline \multicolumn{1}{|c|}{ Somogy } & $\mathbf{1 9 5 8}$ & $\mathbf{1 9 6 3}$ & $\mathbf{1 9 6 8}$ & $\mathbf{1 9 7 4}$ & $\mathbf{1 9 7 9}$ & $\mathbf{1 9 8 4}$ & $\mathbf{1 9 8 9}$ \\
\hline ep & 0.00 & 0.00 & 0.03 & 0.09 & 0.23 & 0.53 & 0.64 \\
\hline tr & 0.48 & 0.45 & 0.44 & 0.30 & 0.21 & 0.11 & 0.02 \\
\hline bu & 0.49 & 0.54 & 0.50 & 0.56 & 0.48 & 0.35 & 0.33 \\
\hline ot & 0.03 & 0.00 & 0.02 & 0.05 & 0.08 & 0.00 & 0.01 \\
\hline BK & 1958 & 1963 & 1968 & 1974 & 1979 & 1984 & 1989 \\
\hline ep & 0.00 & 0.00 & 0.01 & 0.09 & 0.28 & 0.48 & 0.60 \\
\hline tr & 0.50 & 0.52 & 0.47 & 0.43 & 0.33 & 0.19 & 0.14 \\
\hline bu & 0.45 & 0.46 & 0.50 & 0.42 & 0.33 & 0.31 & 0.25 \\
\hline ot & 0.04 & 0.02 & 0.02 & 0.06 & 0.05 & 0.02 & 0.02 \\
\hline \multicolumn{1}{|c|}{ Békés } & 1958 & $\mathbf{1 9 6 3}$ & $\mathbf{1 9 6 8}$ & $\mathbf{1 9 7 4}$ & $\mathbf{1 9 7 9}$ & $\mathbf{1 9 8 4}$ & $\mathbf{1 9 8 9}$ \\
\hline ep & 0.00 & 0.00 & 0.01 & 0.07 & 0.36 & 0.52 & 0.49 \\
\hline tr & 0.05 & 0.10 & 0.07 & 0.06 & 0.07 & 0.02 & 0.01 \\
\hline bu & 0.90 & 0.88 & 0.86 & 0.84 & 0.56 & 0.45 & 0.48 \\
\hline ot & 0.05 & 0.02 & 0.07 & 0.03 & 0.01 & 0.00 & 0.02 \\
\hline
\end{tabular}




\begin{tabular}{|l|c|c|c|c|c|c|c|}
\hline \multicolumn{1}{|c|}{ HB } & $\mathbf{1 9 5 8}$ & $\mathbf{1 9 6 3}$ & $\mathbf{1 9 6 8}$ & $\mathbf{1 9 7 4}$ & $\mathbf{1 9 7 9}$ & $\mathbf{1 9 8 4}$ & $\mathbf{1 9 8 9}$ \\
\hline ep & 0.00 & 0.00 & 0.02 & 0.10 & 0.30 & 0.56 & 0.69 \\
\hline $\mathrm{tr}$ & 0.12 & 0.14 & 0.18 & 0.19 & 0.16 & 0.11 & 0.04 \\
\hline $\mathrm{bu}$ & 0.58 & 0.65 & 0.64 & 0.56 & 0.44 & 0.30 & 0.25 \\
\hline ot & 0.30 & 0.21 & 0.16 & 0.15 & 0.09 & 0.03 & 0.01 \\
\hline \multicolumn{1}{c|}{ SZSZB } & $\mathbf{1 9 5 8}$ & $\mathbf{1 9 6 3}$ & $\mathbf{1 9 6 8}$ & $\mathbf{1 9 7 4}$ & $\mathbf{1 9 7 9}$ & $\mathbf{1 9 8 4}$ & $\mathbf{1 9 8 9}$ \\
\hline ep & 0.00 & 0.00 & 0.00 & 0.08 & 0.25 & 0.48 & 0.64 \\
\hline $\mathrm{tr}$ & 0.09 & 0.12 & 0.14 & 0.24 & 0.19 & 0.12 & 0.07 \\
\hline bu & 0.84 & 0.76 & 0.79 & 0.57 & 0.47 & 0.33 & 0.26 \\
\hline ot & 0.07 & 0.11 & 0.06 & 0.11 & 0.09 & 0.06 & 0.03 \\
\hline
\end{tabular}

Table 3. Proportion of nest sites by counties in the 1958-1989 period, based on questionnaires 3. táblázat A fészekalapok arányai megyénként az 1958-1989-es periódusban, a kérdőívek alapján

\begin{tabular}{|l|c|c|c|c|c|c|c|}
\hline \multicolumn{1}{|c|}{ GYMS } & $\mathbf{1 9 5 8}$ & $\mathbf{1 9 6 3}$ & $\mathbf{1 9 6 8}$ & $\mathbf{1 9 7 4}$ & $\mathbf{1 9 7 9}$ & $\mathbf{1 9 8 4}$ & $\mathbf{1 9 8 9}$ \\
\hline ep & 0.00 & 0.01 & 0.05 & 0.12 & 0.27 & 0.49 & 0.73 \\
\hline ot & 0.03 & 0.01 & 0.02 & 0.03 & 0.01 & 0.00 & 0.04 \\
\hline ro & 0.29 & 0.21 & 0.32 & 0.18 & 0.07 & 0.02 & 0.00 \\
\hline ch & 0.59 & 0.63 & 0.52 & 0.62 & 0.61 & 0.44 & 0.23 \\
\hline tr & 0.09 & 0.15 & 0.09 & 0.04 & 0.04 & 0.04 & 0.00 \\
\hline \multicolumn{1}{|c|}{ Somogy } & 1958 & $\mathbf{1 9 6 3}$ & $\mathbf{1 9 6 8}$ & $\mathbf{1 9 7 4}$ & $\mathbf{1 9 7 9}$ & $\mathbf{1 9 8 4}$ & $\mathbf{1 9 8 9}$ \\
\hline ep & 0.00 & 0.00 & 0.05 & 0.21 & 0.28 & 0.58 & 0.68 \\
\hline ot & 0.06 & 0.06 & 0.03 & 0.02 & 0.00 & 0.03 & 0.01 \\
\hline ro & 0.11 & 0.22 & 0.13 & 0.09 & 0.01 & 0.04 & 0.03 \\
\hline ch & 0.23 & 0.32 & 0.61 & 0.45 & 0.57 & 0.29 & 0.21 \\
\hline tr & 0.60 & 0.40 & 0.18 & 0.24 & 0.14 & 0.06 & 0.07 \\
\hline BK & 1958 & 1963 & 1968 & 1974 & 1979 & 1984 & 1989 \\
\hline ep & 0.00 & 0.00 & 0.05 & 0.12 & 0.35 & 0.44 & 0.52 \\
\hline ot & 0.00 & 0.02 & 0.05 & 0.07 & 0.05 & 0.00 & 0.02 \\
\hline ro & 0.00 & 0.00 & 0.09 & 0.09 & 0.01 & 0.01 & 0.11 \\
\hline ch & 0.00 & 0.14 & 0.27 & 0.36 & 0.25 & 0.32 & 0.32 \\
\hline tr & 1.00 & 0.84 & 0.55 & 0.35 & 0.34 & 0.22 & 0.03 \\
\hline \multicolumn{1}{c|}{ Békés } & 1958 & $\mathbf{1 9 6 3}$ & $\mathbf{1 9 6 8}$ & $\mathbf{1 9 7 4}$ & $\mathbf{1 9 7 9}$ & $\mathbf{1 9 8 4}$ & $\mathbf{1 9 8 9}$ \\
\hline ep & 0.00 & 0.00 & 0.00 & 0.07 & 0.29 & 0.55 & 0.57 \\
\hline ot & 0.00 & 0.03 & 0.03 & 0.07 & 0.03 & 0.01 & 0.05 \\
\hline ro & 0.00 & 0.00 & 0.03 & 0.01 & 0.01 & 0.02 & 0.00 \\
\hline ch & 1.00 & 0.90 & 0.93 & 0.82 & 0.64 & 0.37 & 0.34 \\
\hline tr & 0.00 & 0.06 & 0.03 & 0.03 & 0.03 & 0.05 & 0.03 \\
\hline HB & 1958 & 1963 & 1968 & 1974 & 1979 & 1984 & 1989 \\
\hline ep & 0.00 & 0.00 & 0.04 & 0.38 & 0.50 & 0.71 & 0.91 \\
\hline
\end{tabular}




\begin{tabular}{|l|c|c|c|c|c|c|c|}
\hline \multicolumn{1}{|c|}{ Békés } & $\mathbf{1 9 5 8}$ & $\mathbf{1 9 6 3}$ & $\mathbf{1 9 6 8}$ & $\mathbf{1 9 7 4}$ & $\mathbf{1 9 7 9}$ & $\mathbf{1 9 8 4}$ & $\mathbf{1 9 8 9}$ \\
\hline ot & 0.00 & 0.00 & 0.05 & 0.11 & 0.02 & 0.03 & 0.01 \\
\hline ro & 0.17 & 0.00 & 0.55 & 0.11 & 0.09 & 0.03 & 0.00 \\
\hline ch & 0.75 & 0.00 & 0.19 & 0.28 & 0.27 & 0.16 & 0.06 \\
\hline tr & 0.08 & 1.00 & 0.17 & 0.11 & 0.13 & 0.06 & 0.02 \\
\hline \multicolumn{1}{c|}{ SZSZB } & 1958 & 1963 & 1968 & 1974 & 1979 & 1984 & 1989 \\
\hline ep & 0.00 & 0.00 & 0.01 & 0.05 & 0.44 & 0.60 & 0.70 \\
\hline ot & 0.00 & 0.01 & 0.01 & 0.01 & 0.04 & 0.02 & 0.16 \\
\hline ro & 0.28 & 0.55 & 0.68 & 0.24 & 0.22 & 0.14 & 0.06 \\
\hline ch & 0.51 & 0.32 & 0.12 & 0.53 & 0.17 & 0.14 & 0.06 \\
\hline tr & 0.21 & 0.12 & 0.19 & 0.16 & 0.13 & 0.10 & 0.03 \\
\hline
\end{tabular}

Table 4. Linear regression of nest sites by counties in the 1958-1989 period. The first abbrevation indicates the nest site, the second the data source in the upper left corners

4. táblázat A fészekalapok lineáris regressziói megyénként az 1958-1989-es periódusban. Az első rövidítés a fészekalapot, a második a felmérés típusát jelzi minden bal felső sarokban

\begin{tabular}{|c|c|c|c|c|c|c|c|c|c|}
\hline \\
\hline \multicolumn{2}{|c|}{ estimate std error t value } & std. error & t value & $p$ value & ep (po) & estimate & std. error & t value & \\
\hline (intercept) & -44.45 & 8.463 & -5.252 & 0.003 & (intercept) & -39.433 & 6.696 & -5.889 & 0.002 \\
\hline year & 0.023 & 0.004 & 5.28 & 0.003 & year & 0.02 & 0.003 & 5.919 & 0.002 \\
\hline $\operatorname{tr}(q u)$ & estimate & std. error & t value & $p$ value & $\operatorname{tr}(\mathrm{po})$ & estimate & std. error & t value & $\mathrm{p}$ value \\
\hline (intercept) & 7.091 & 1.996 & 3.553 & 0.016 & (intercept) & 6.769 & 2.069 & 3.272 & 0.022 \\
\hline year & -0.004 & 0.001 & -3.522 & 0.017 & year & -0.003 & 0.001 & -3.237 & 0.023 \\
\hline ro (qu) & estimate & std. error & t value & $\mathrm{p}$ value & bu (po) & estimate & std. error & t value & p value \\
\hline (intercept) & 19.274 & 3.679 & 5.239 & 0.003 & (intercept) & 30.683 & 6.612 & 4.64 & 0.006 \\
\hline year & -0.01 & 0.002 & -5.199 & 0.003 & year & -0.015 & 0.003 & -4.538 & 0.006 \\
\hline ch (qu) & estimate & std. error & t value & $p$ value & bu (qu) & estimate & std. error & t value & $\mathrm{p}$ value \\
\hline (intercept) & 17.711 & 7.228 & 2.45 & 0.058 & (intercept) & 36.985 & 7.148 & 5.174 & 0.004 \\
\hline year & -0.009 & 0.004 & -2.382 & 0.063 & year & -0.018 & 0.004 & -5.085 & 0.004 \\
\hline ot (qu) & estimate & std. error & $\mathrm{t}$ value & $p$ value & ot (po) & estimate & std. error & t value & $p$ value \\
\hline (intercept) & -0.124 & 1.08 & -0.115 & 0.913 & (intercept) & 2.981 & 0.747 & 3.992 & 0.01 \\
\hline year & 0 & 0.001 & 0.133 & 0.9 & year & -0.001 & 0 & -3.931 & 0.011 \\
\hline
\end{tabular}

\begin{tabular}{|c|c|c|c|c|c|c|c|c|c|}
\hline \\
\hline \multicolumn{10}{|l|}{\begin{tabular}{|l} 
Somogy \\
ep (qu)
\end{tabular}} \\
\hline (intercept) & -43.384 & 6.158 & -7.045 & 0.001 & (intercept) & -42.891 & 8.095 & -5.298 & 0.003 \\
\hline year & 0.022 & 0.003 & 7.084 & 0.001 & year & 0.022 & 0.004 & 5.326 & 0.003 \\
\hline $\operatorname{tr}(q u)$ & estimate & std. error & $\mathrm{t}$ value & $p$ value & $\operatorname{tr}(\mathrm{po})$ & estimate & std. error & $\mathrm{t}$ value & $\mathrm{p}$ value \\
\hline (intercept) & 28.104 & 5.95 & 4.723 & 0.005 & (intercept) & 31.224 & 2.918 & 10.7 & $1.23 \mathrm{E}-04$ \\
\hline year & -0.014 & 0.003 & -4.686 & 0.005 & year & -0.016 & 0.001 & -10.6 & $1.29 \mathrm{E}-04$ \\
\hline ro (qu) & estimate & std. error & t value & $\mathrm{p}$ value & bu (po) & estimate & std. error & t value & $p$ value \\
\hline (intercept) & 9.117 & 3.355 & 2.718 & 0.042 & (intercept) & 12.521 & 4.617 & 2.712 & 0.042 \\
\hline year & -0.005 & 0.002 & -2.693 & 0.043 & year & -0.006 & 0.002 & -2.611 & 0.048 \\
\hline ch (qu) & estimate & std. error & t value & $p$ value & bu (qu) & estimate & std. error & t value & $p$ value \\
\hline (intercept) & 0.835 & 11.027 & 0.076 & 0.943 & (intercept) & 9.952 & 10.872 & 0.915 & 0.402 \\
\hline year & 0 & 0.006 & -0.044 & 0.967 & year & -0.005 & 0.006 & -0.876 & 0.421 \\
\hline ot (qu) & estimate & std. error & t value & p value & ot (po) & estimate & std. error & t value & $p$ value \\
\hline (intercept) & 2.827 & 1.047 & 2.701 & 0.043 & (intercept) & 0.147 & 2.2 & 0.067 & 0.949 \\
\hline year & -0.001 & 0.001 & -2.677 & 0.044 & year & 0 & 0.001 & -0.054 & 0.959 \\
\hline
\end{tabular}




\begin{tabular}{|c|c|c|c|c|c|c|c|c|c|}
\hline \multicolumn{10}{|l|}{ BK } \\
\hline \multicolumn{10}{|c|}{ estimate std. error t value } \\
\hline (intercept) & -33.344 & 4.436 & -7.517 & 0.001 & (intercept) & -40.575 & 6.877 & -5.9 & 0.002 \\
\hline year & 0.017 & 0.002 & 7.56 & 0.001 & year & 0.021 & 0.003 & 5.931 & 0.002 \\
\hline $\operatorname{tr}(q u)$ & estimate & std. error & $\mathrm{t}$ value & $\mathrm{p}$ value & $\operatorname{tr}(\mathrm{po})$ & estimate & std. error & t value & p value \\
\hline (intercept) & 60.072 & 5.441 & 11.04 & $1.06 \mathrm{E}-04$ & (intercept) & 25.914 & 3.772 & 6.869 & 0.001 \\
\hline year & -0.03 & 0.003 & -10.96 & 1.10E-04 & year & -0.013 & 0.002 & -6.772 & 0.001 \\
\hline ro (qu) & estimate & std. error & t value & $p$ value & bu (po) & estimate & std. error & t value & $p$ value \\
\hline (intercept) & -3.317 & 3.528 & -0.94 & 0.39 & (intercept) & 14.846 & 3.109 & 4.775 & 0.005 \\
\hline year & 0.002 & 0.002 & 0.953 & 0.385 & year & -0.007 & 0.002 & -4.65 & 0.006 \\
\hline ch (qu) & estimate & std. error & t value & $p$ value & bu (qu) & estimate & std. error & t value & $p$ value \\
\hline (intercept) & -14.988 & 6.22 & -2.41 & 0.061 & (intercept) & -18.305 & 9.027 & -2.028 & 0.098 \\
\hline year & 0.008 & 0.003 & 2.446 & 0.058 & year & 0.009 & 0.005 & 2.057 & 0.095 \\
\hline ot (qu) & estimate & std. error & t value & $\mathrm{p}$ value & ot (po) & estimate & std. error & t value & $p$ value \\
\hline (intercept) & -0.362 & 1.96 & -0.185 & 0.861 & (intercept) & 0.815 & 1.374 & 0.593 & 0.579 \\
\hline year & 0 & 0.001 & 0.199 & 0.85 & year & 0 & 0.001 & -0.568 & 0.594 \\
\hline
\end{tabular}

\begin{tabular}{|l|rrrr|l|rrrr|}
\hline Békés & \multicolumn{10}{|l|}{ ep (qu) } & estimate & std. error & t value & p value & ep (po) & estimate & std. error & t value & $p$ value \\
(intercept) & -39.41 & 7.463 & -5.28 & 0.003 & (intercept) & -38.636 & 7.441 & -5.192 & 0.003 \\
year & 0.02 & 0.004 & 5.307 & 0.003 & year & 0.02 & 0.004 & 5.22 & 0.003 \\
\hline tr (qu) & estimate & std. error & t value & p value & tr (po) & estimate & std. error & t value & $p$ value \\
(intercept) & -0.644 & 1.527 & -0.422 & 0.691 & (intercept) & 3.847 & 1.721 & 2.235 & 0.076 \\
year & 0 & 0.001 & 0.442 & 0.677 & year & -0.002 & 0.001 & -2.204 & 0.079 \\
\hline ro (qu) & estimate & std. error & t value & p value & bu (po) & estimate & std. error & t value & $p$ value \\
(intercept) & -0.498 & 0.731 & -0.681 & 0.526 & (intercept) & 33.224 & 6.257 & 5.31 & 0.003 \\
year & 0 & 0 & 0.695 & 0.518 & year & -0.016 & 0.003 & -5.196 & 0.003 \\
\hline ch (qu) & estimate & std. error & t value & p value & bu (qu) & estimate & std. error & t value & $p$ value \\
(intercept) & 47.095 & 5.98 & 7.875 & 0.001 & (intercept) & 46.598 & 6.322 & 7.371 & 0.001 \\
year & -0.024 & 0.003 & -7.759 & 0.001 & year & -0.023 & 0.003 & -7.259 & 0.001 \\
\hline ot (qu) & estimate & std. error & t value & p value & ot (po) & estimate & std. error & t value & $p$ value \\
(intercept) & -1.403 & 1.666 & -0.842 & 0.438 & (intercept) & 2.565 & 1.489 & 1.722 & 0.146 \\
year & 0.001 & 0.001 & 0.86 & 0.429 & year & -0.001 & 0.001 & -1.704 & 0.149 \\
\hline
\end{tabular}

\begin{tabular}{|c|c|c|c|c|c|c|c|c|c|}
\hline \\
\hline \multicolumn{10}{|l|}{$\begin{array}{l}\mathrm{HB} \\
\text { ep (qu) }\end{array}$} \\
\hline (intercept) & -59.628 & 6.427 & -9.278 & $2.45 \mathrm{E}-04$ & (intercept) & -46.585 & 8.099 & -5.752 & 0.002 \\
\hline year & 0.03 & 0.003 & 9.332 & $2.38 \mathrm{E}-04$ & year & 0.024 & 0.004 & 5.781 & 0.002 \\
\hline $\operatorname{tr}(q u)$ & estimate & std. error & t value & $p$ value & $\operatorname{tr}(\mathrm{po})$ & estimate & std. error & t value & $\mathrm{p}$ value \\
\hline (intercept) & 28.91 & 23.822 & 1.214 & 0.279 & (intercept) & 4.186 & 3.434 & 1.219 & 0.277 \\
\hline year & -0.015 & 0.012 & -1.204 & 0.282 & year & -0.002 & 0.002 & -1.179 & 0.291 \\
\hline ro (qu) & estimate & std. error & t value & $p$ value & bu (po) & estimate & std. error & t value & p value \\
\hline (intercept) & 12.439 & 13.526 & 0.92 & 0.4 & (intercept) & 25.841 & 5.439 & 4.751 & 0.005 \\
\hline year & -0.006 & 0.007 & -0.91 & 0.405 & year & -0.013 & 0.003 & -4.661 & 0.006 \\
\hline $\operatorname{ch}(q u)$ & estimate & std. error & t value & $p$ value & bu (qu) & estimate & std. error & t value & $p$ value \\
\hline (intercept) & 22.642 & 16.464 & 1.375 & 0.227 & (intercept) & 35.081 & 21.522 & 1.63 & 0.164 \\
\hline year & -0.011 & 0.008 & -1.361 & 0.232 & year & -0.018 & 0.011 & -1.613 & 0.168 \\
\hline ot (qu) & estimate & std. error & t value & $p$ value & ot (po) & estimate & std. error & t value & $\mathrm{p}$ value \\
\hline (intercept) & -0.933 & 3.097 & -0.301 & 0.775 & (intercept) & 17.559 & 1.757 & 9.994 & $1.71 \mathrm{E}-04$ \\
\hline year & 0 & 0.002 & 0.311 & 0.768 & year & -0.009 & 0.001 & -9.916 & $1.78 \mathrm{E}-04$ \\
\hline
\end{tabular}




\begin{tabular}{|c|c|c|c|c|c|c|c|c|c|}
\hline \\
\hline \multicolumn{10}{|l|}{\begin{tabular}{|l} 
SZSZB \\
ep (qu)
\end{tabular}} \\
\hline (intercept) & -48.538 & 9.287 & -5.226 & 0.003 & (intercept) & -41.858 & 7.804 & -5.364 & 0.003 \\
\hline year & 0.025 & 0.005 & 5.253 & 0.003 & year & 0.021 & 0.004 & 5.391 & 0.003 \\
\hline $\operatorname{tr}(q u)$ & estimate & std. error & t value & $p$ value & $\operatorname{tr}(\mathrm{po})$ & estimate & std. error & t value & $\mathrm{p}$ value \\
\hline (intercept) & 7.78 & 2.518 & 3.09 & 0.027 & (intercept) & 0.42 & 4.567 & 0.092 & 0.93 \\
\hline year & -0.004 & 0.001 & -3.041 & 0.029 & year & 0 & 0.002 & -0.061 & 0.953 \\
\hline ro (qu) & estimate & std. error & t value & $p$ value & bu (po) & estimate & std. error & t value & $p$ value \\
\hline (intercept) & 24.5 & 13.074 & 1.874 & 0.12 & (intercept) & 40.044 & 3.951 & 10.135 & $1.60 \mathrm{E}-04$ \\
\hline year & -0.012 & 0.007 & -1.852 & 0.123 & year & -0.02 & 0.002 & -9.989 & 1.72E-04 \\
\hline ch (qu) & estimate & std. error & t value & $p$ value & bu (qu) & estimate & std. error & t value & $p$ value \\
\hline (intercept) & 18.423 & 10.187 & 1.809 & 0.13 & (intercept) & 42.923 & 10.148 & 4.23 & 0.008 \\
\hline year & -0.009 & 0.005 & -1.785 & 0.134 & year & -0.021 & 0.005 & -4.177 & 0.009 \\
\hline ot (qu) & estimate & std. error & t value & $p$ value & ot (po) & estimate & std. error & t value & $\mathrm{p}$ value \\
\hline (intercept) & -6.792 & 2.854 & -2.38 & 0.063 & (intercept) & 2.394 & 2.037 & 1.175 & 0.293 \\
\hline year & 0.003 & 0.001 & 2.393 & 0.062 & year & -0.001 & 0.001 & -1.137 & 0.307 \\
\hline
\end{tabular}

Table 5. LMM of nest sites for the 1958-1989 period. First part indicates the nest site, second part the type of variable in the upper left corners. The model compares the postal form to the questionnaires

5. táblázat A fészekalapok lineáris vegyes modellje az 1958-1989-es periódusra. Az első szó a fészekalapot, a második a változó típusát jelzi minden bal felső sarokban. A modell a postai adatlapot hasonlítja a kérdőívekhez

\begin{tabular}{|c|c|c|c|c|c|c|c|}
\hline bu, random: & & variance & std. dev. & ep, random: & & variance & std. dev. \\
\hline county & (intercept) & 0.01957 & 0.1399 & county & (intercept) & 0.000475 & 0.0218 \\
\hline residual & & 0.02307 & 0.1519 & residual & & 0.010079 & 0.1004 \\
\hline bu, fixed: & estimate & std. error & t value & ep, fixed: & estimate & std. error & t value \\
\hline (intercept) & 25.8368 & 3.136143 & 8.238 & (intercept) & -43.2131 & 2.0725 & -20.851 \\
\hline year & -0.01284 & 0.001589 & -8.083 & year & 0.02202 & 0.00105 & 20.969 \\
\hline source (po) & 0.058383 & 0.033146 & 1.761 & source (po) & -0.02919 & 0.02191 & -1.332 \\
\hline tr, random: & & variance & std. dev. & eg, random: & & variance & std. dev. \\
\hline county & (intercept) & 0.0175 & 0.1323 & county & (intercept) & 0.000387 & 0.01967 \\
\hline residual & & 0.01926 & 0.1388 & residual & & 0.001837 & 0.04286 \\
\hline tr, fixed: & estimate & std. error & t value & eg, fixed: & estimate & std. error & t value \\
\hline (intercept) & 16.97768 & 2.865058 & 5.926 & (intercept) & 1.62465 & 0.88471 & 1.836 \\
\hline year & -0.00851 & 0.001451 & -5.862 & year & -0.00081 & 0.000448 & -1.804 \\
\hline source (po) & -0.01018 & 0.030281 & -0.336 & source (po) & 0.029663 & 0.009352 & 3.172 \\
\hline
\end{tabular}




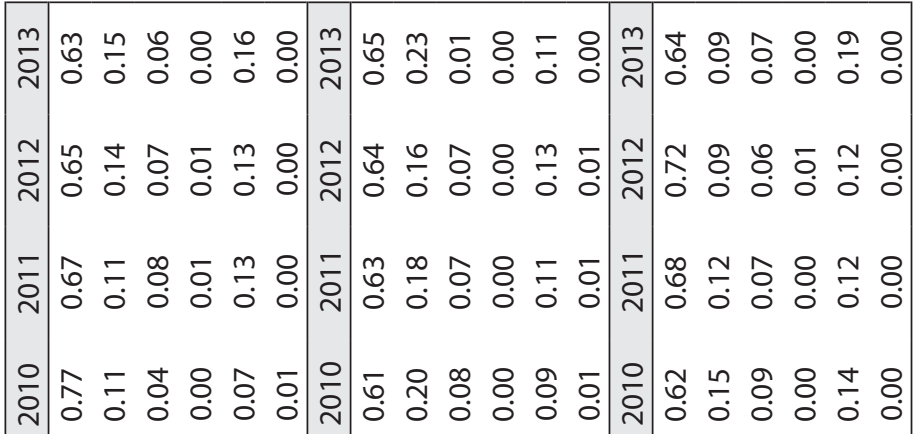
市诰 年

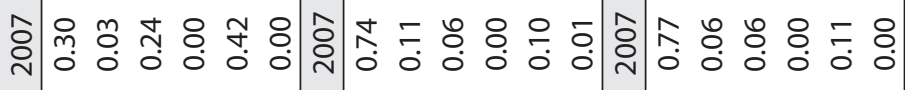
市

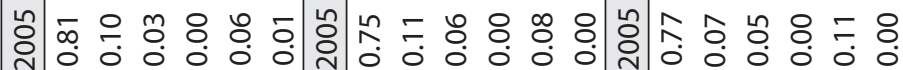

究

$\frac{m}{0} \frac{\pi}{n}$

กั

ปे

담

๕ ๙

$\stackrel{\circ}{5}$

일

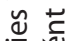

至

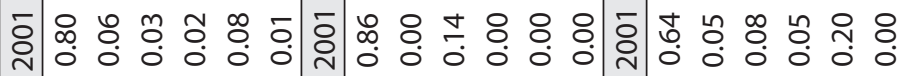
สิ ฮิ

$\stackrel{\frac{\pi}{2}}{\stackrel{0}{*}}$

৪)

$\stackrel{\tilde{y}}{\frac{\pi}{\sigma}}$

प्र

Кे

등 $\frac{\pi}{\pi}$

일

은 迎

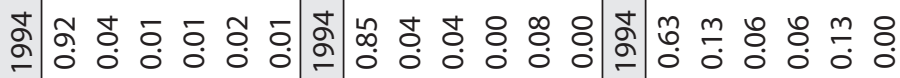

$6: \sqrt{2}$

$\frac{0}{0} \frac{1}{2}$

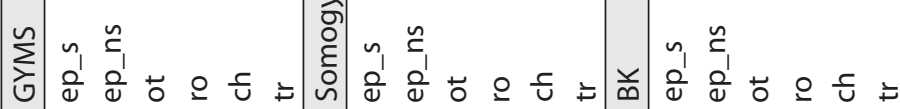




\begin{tabular}{|c|c|}
\hline 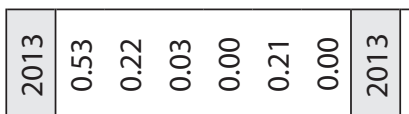 & 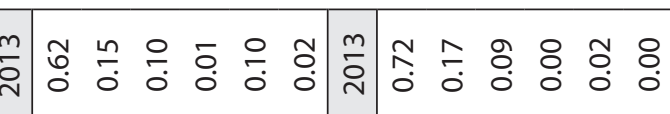 \\
\hline 1000 & 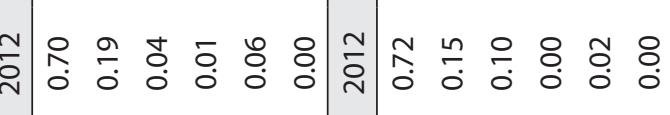 \\
\hline 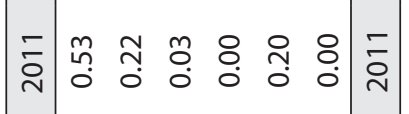 & 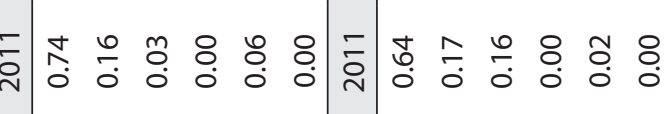 \\
\hline 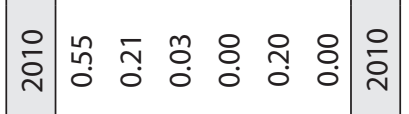 & 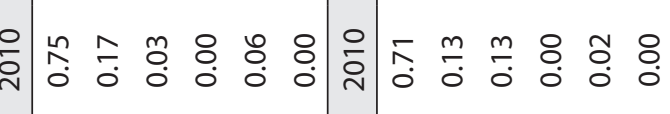 \\
\hline : & : \\
\hline & : \\
\hline & 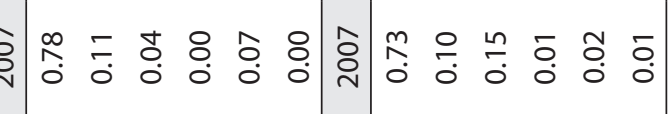 \\
\hline 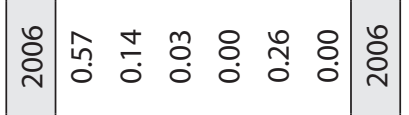 & : \\
\hline & 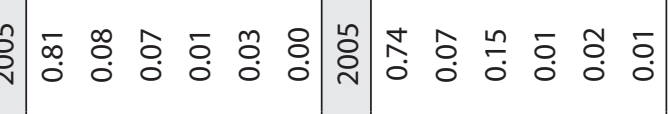 \\
\hline 客 & S: \\
\hline & $\stackrel{0}{\circ}$ \\
\hline ๐ั & 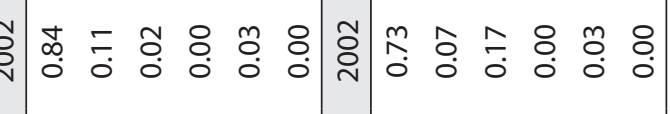 \\
\hline & 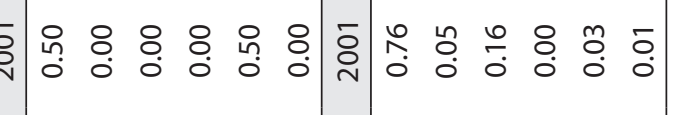 \\
\hline & 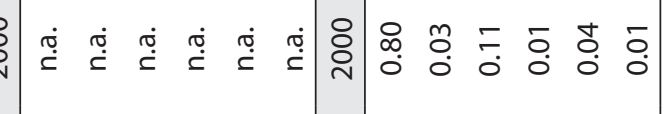 \\
\hline & 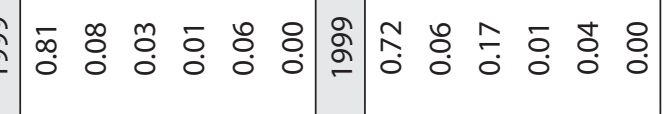 \\
\hline & 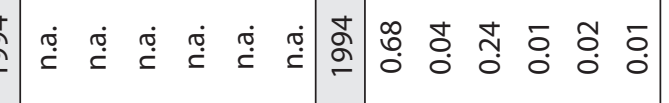 \\
\hline & \\
\hline
\end{tabular}


Table 7. Linear regression of nest sites by counties in the 1994-2013 period. The abbrevation indicates the nest site in the upper left corners

7. táblázat A fészekalapok lineáris regressziói megyénként az 1994-2013-as periódusban. A rövidítés a fészekalapot jelzi minden bal felső sarokban

\begin{tabular}{|c|c|c|c|c|c|c|c|c|c|}
\hline GYMS & & & & & Békés & & & & \\
\hline ep & estimate & std. error $t$ & t value & $p$ value & ep & estimate & std. error & ralue & value \\
\hline (intercept) & 12.055 & 23.511 & 0.513 & 0.616 & (intercept) & -27.214 & 8.605 & -3.163 & 0.009 \\
\hline year & -0.006 & 0.012 & -0.48 & 0.638 & year & 0.014 & 0.004 & 3.245 & 0.008 \\
\hline ep_s & estimate & std. error $t$ & $\mathrm{t}$ value & $p$ value & ep_s & estimate & std. error & galue & value \\
\hline (intercept) & 25.291 & 21.79 & 1.161 & 0.265 & (intercept) & 6.802 & 6.998 & 0.972 & 0.352 \\
\hline year & -0.012 & 0.011 & -1.129 & 0.278 & year & -0.003 & 0.003 & -0.891 & 0.392 \\
\hline ep_ns & estimate & std. error $t$ & t value & $p$ value & ep_ns & estimate & std. error & ialue & value \\
\hline (intercept) & -13.236 & 3.459 & -3.827 & 0.002 & (intercept) & -34.016 & 3.434 & -9.907 & $8.12 \mathrm{E}-07$ \\
\hline year & 0.007 & 0.002 & 3.847 & 0.002 & year & 0.017 & 0.002 & 9.948 & $7.79 \mathrm{E}-07$ \\
\hline ro & estimate & std. error $t$ & $\mathrm{t}$ value & $p$ value & ro & estimate & std. error & ralue & value \\
\hline (intercept) & 1.153 & 1.226 & 0.941 & 0.363 & (intercept) & -0.684 & 0.146 & -4.692 & 0.001 \\
\hline year & -0.001 & 0.001 & -0.936 & 0.365 & year & 0 & 0 & 4.704 & 0.001 \\
\hline ch & estimate & std. error $t$ & t value & $p$ value & ch & estimate & std. error & ralue & value \\
\hline (intercept) & -15.258 & 13.921 & -1.096 & 0.292 & (intercept) & 31.495 & 9.817 & 3.208 & 0.008 \\
\hline year & 0.008 & 0.007 & 1.106 & 0.287 & year & -0.016 & 0.005 & -3.182 & 0.009 \\
\hline $\operatorname{tr}$ & estimate & std. error $t$ & t value & $\mathrm{p}$ value & $\operatorname{tr}$ & estimate & std. error & ialue & value \\
\hline (intercept) & 0.632 & 0.2932 & 2014.02 .16 & 0.049 & (intercept) & 0.089 & 0.487 & 0.183 & 0.858 \\
\hline year & 0 & 0 & -2.15 & 0.05 & year & 0 & 0 & -0.178 & 0.862 \\
\hline ot & estimate & std. error $t$ & $\mathrm{t}$ value & $p$ value & ot & estimate & std. error & ralue & value \\
\hline (intercept) & 2.418 & 12.595 & 0.192 & 0.851 & (intercept) & -2.686 & 1.157 & -2.321 & 0.041 \\
\hline year & -0.001 & 0.006 & -0.185 & 0.856 & year & 0.001 & 0.001 & 2.346 & 0.039 \\
\hline Somogy & & & & & $\mathrm{HB}$ & & & & \\
\hline ep & estimate & std. error $\mathrm{t}$ & $\mathrm{t}$ value & $p$ value & ep & estimate & std. error & alue & value \\
\hline (intercept) & 6.401 & 2.523 & 2.537 & 0.024 & (intercept) & -8.79 & 14.672 & -0.599 & 0.56 \\
\hline year & -0.003 & 0.001 & -2.202 & 0.045 & year & 0.005 & 0.007 & 0.658 & 0.523 \\
\hline ep_s & estimate & std. error $t$ & $\mathrm{t}$ value & $p$ value & ep_s & estimate & std. error & ralue & value \\
\hline (intercept) & 27.541 & 4.871 & 5.654 & 5.95E-05 & (intercept) & 32.357 & 4.362 & 7.417 & 2.27E-05 \\
\hline year & -0.013 & 0.002 & -5.502 & $7.80 \mathrm{E}-05$ & year & -0.016 & 0.002 & -7.242 & 2.79E-05 \\
\hline ep_ns & estimate & std. error $t$ & $\mathrm{t}$ value & $\mathrm{p}$ value & ep_ns & estimate & std. error & ralue & value \\
\hline (intercept) & -21.141 & 4.162 & -5.08 & $1.68 \mathrm{E}-04$ & (intercept) & -18.344 & 3.896 & -4.709 & 0.001 \\
\hline year & 0.011 & 0.002 & 5.105 & $1.60 \mathrm{E}-04$ & year & 0.009 & 0.002 & 4.741 & 0.001 \\
\hline ro & estimate & std. error $t$ & t value & $p$ value & ro & estimate & std. error & Ialue & value \\
\hline (intercept) & 0 & & NA & NA & (intercept) & -0.286 & 0.641 & -0.447 & 0.665 \\
\hline year & 0 & $0 N$ & NA & NA & year & 0 & $3.20 \mathrm{E}-04$ & 0.453 & 0.661 \\
\hline ch & estimate & std. error $t$ & $\mathrm{t}$ value & $p$ value & ch & estimate & std. error & alue & value \\
\hline (intercept) & -7.547 & 3.642 & -2.072 & 0.057 & (intercept) & -5.164 & 3.566 & -1.448 & 0.178 \\
\hline year & 0.004 & 0.002 & 2.094 & 0.055 & year & 0.003 & 0.002 & 1.466 & 0.173 \\
\hline $\operatorname{tr}$ & estimate & std. error $t$ & $\mathrm{t}$ value & $p$ value & tr & estimate & std. error & alue & value \\
\hline (intercept) & -0.756 & 0.355 & -2.128 & 0.052 & (intercept) & -2.041 & 0.841 & -2.427 & 0.036 \\
\hline year & 0 & $1.77 \mathrm{E}-04$ & 2.14 & 0.051 & year & 0.001 & 4.19E-04 & 2.43 & 0.035 \\
\hline ot & estimate & std. error $\mathrm{t}$ & $\mathrm{t}$ value & $p$ value & ot & estimate & std. error & ralue & value \\
\hline (intercept) & 2.902 & 3.549 & 0.818 & 0.427 & (intercept) & -5.522 & 3.706 & -1.49 & 0.167 \\
\hline year & -0.001 & 0.002 & -0.797 & 0.439 & year & 0.003 & 0.002 & 1.501 & 0.164 \\
\hline
\end{tabular}




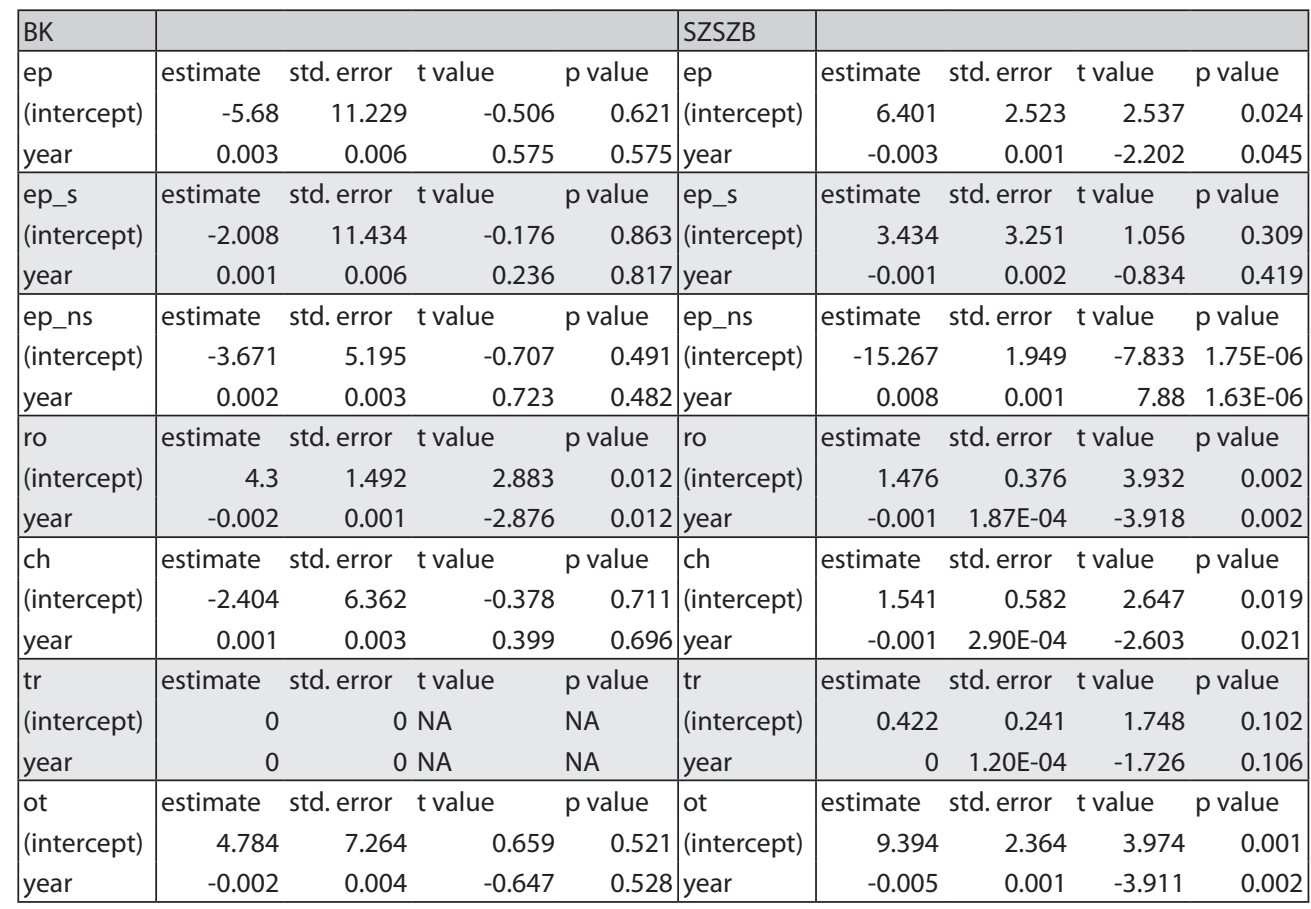

Table 8. LMM of nest sites for the 1994-2013 period. First part indicates the nest site, the second the type of variable in the upper left corners

8. táblázat A fészekalapok lineáris vegyes modellje az 1994-2013-es periódusra. Az első szó a fészekalapot, a második a változó típusát jelzi minden bal felső sarokban

\begin{tabular}{|c|c|c|c|c|c|c|c|}
\hline ep, random & & variance & std. dev. & ch, random & & variance & std. dev. \\
\hline megye & (intercept) & 0.002 & 0.047 & megye & (intercept) & 0.006 & 0.075 \\
\hline residual & & 0.015 & 0.122 & residual & & 0.008 & 0.089 \\
\hline ep, fixed & & std. error & t value & ch, fixed & estimate & std. error & t value \\
\hline (intercept) & -2.879 & 5.361 & -0.537 & (intercept) & -0.293 & 3.904 & -0.075 \\
\hline year & 0.002 & 0.003 & 0.685 & year & $2.06 \mathrm{E}-04$ & 0.002 & 0.106 \\
\hline ep_s, random & & variance & std. dev. & tr, random & & variance & std. dev. \\
\hline megye & (intercept) & 0.003 & 0.056 & megye & (intercept) & $2.62 \mathrm{E}-06$ & 0.002 \\
\hline residual & & 0.013 & 0.116 & residual & & $1.23 \mathrm{E}-05$ & 0.004 \\
\hline ep_s, fixed & estimate & std. error & t value & tr, fixed & estimate & std. error & t value \\
\hline (intercept) & 13.034 & 5.081 & 2.565 & (intercept) & -0.073 & 0.154 & -0.474 \\
\hline year & -0.006 & 0.003 & -2.429 & year & 3.77E-05 & $7.65 \mathrm{E}-05$ & 0.493 \\
\hline ep_ns, random & & variance & std. dev. & ot, random & & variance & std. dev. \\
\hline megye & (intercept) & $2.90 \mathrm{E}-04$ & 0.017 & megye & (intercept) & 0.002 & 0.039 \\
\hline residual & & 0.002 & 0.041 & residual & & 0.004 & 0.064 \\
\hline ep_ns, fixed & estimate & std. error & t value & ot, fixed & estimate & std. error & t value \\
\hline (intercept) & -16.1 & 1.78 & -9.036 & (intercept) & 3.298 & 2.825 & 1.168 \\
\hline year & 0.008 & 0.001 & 9.093 & year & -0.002 & 0.001 & -1.14 \\
\hline ro, random & & variance & std. dev. & & & & \\
\hline megye & (intercept) & 4.47E-06 & 0,002 & & & & \\
\hline residual & & $8.54 \mathrm{E}-05$ & 0.009 & & & & \\
\hline ro, fixed & estimate & std. error & t value & & & & \\
\hline (intercept) & 1.331 & 0.404 & 3.298 & & & & \\
\hline year & -0.001 & $2.01 \mathrm{E}-04$ & -3.287 & & & & \\
\hline
\end{tabular}


Table 9. Linear regressions of the unoccupied nests on electricity poles with support (left column) and the empty electricity poles with support (right column) by counties

9. táblázat Lineáris regresszió a lakatlan fészkekre fészektartós villanyoszlopon (bal oszlop) és az üres fészektartókra villanyoszlopon (jobb oszlop)

\begin{tabular}{|c|c|c|c|c|c|c|c|c|c|}
\hline \multicolumn{5}{|c|}{ ep_t, unoccupied } & \multicolumn{5}{|c|}{ ep_t, empty } \\
\hline GYMS & estimate & std.error & $\mathrm{t}$ value & $p$ value & GYMS & estimate & std.error & t value & $p$ value \\
\hline (intercept) & 12.743 & 23.652 & 0.539 & 0.599 & (intercept) & -5.012 & 7.136 & -0.702 & 0.494 \\
\hline year & -0.006 & 0.012 & -0.532 & 0.603 & year & 0.003 & 0.004 & 0.709 & 0.49 \\
\hline Somogy & estimate & std.error & t value & $p$ value & Somogy & estimate & std.error & $\mathrm{t}$ value & $p$ value \\
\hline (intercept) & -23.561 & 8.829 & -2.669 & 0.018 & (intercept) & -42.858 & 8.704 & -4.924 & $2.24 \mathrm{E}-04$ \\
\hline year & 0.012 & 0.004 & 2.689 & 0.018 & year & 0.021 & 0.004 & 4.938 & $2.18 \mathrm{E}-04$ \\
\hline BK & estimate & std.error & t value & $p$ value & BK & estimate & std.error & t value & $p$ value \\
\hline (intercept) & -10.625 & 5.191 & -2.047 & 0.06 & (intercept) & -14.806 & 3.804 & -3.892 & 0.002 \\
\hline year & 0.005 & 0.003 & 2.063 & 0.058 & year & 0.007 & 0.002 & 3.909 & 0.002 \\
\hline Békés & estimate & std.error & t value & $p$ value & Békés & estimate & std.error & t value & $p$ value \\
\hline (intercept) & -5.923 & 7.007 & -0.845 & 0.415 & (intercept) & 0.234 & 3.146 & 0.074 & 0.942 \\
\hline year & 0.003 & 0.003 & 0.86 & 0.407 & year & 0 & 0.002 & -0.069 & 0.946 \\
\hline $\mathrm{HB}$ & estimate & std.error & t value & $\mathrm{p}$ value & $\mathrm{HB}$ & estimate & std.error & t value & $p$ value \\
\hline (intercept) & 15.972 & 14.53 & 1.099 & 0.293 & (intercept) & -44.326 & 7.456 & -5.945 & $6.76 \mathrm{E}-05$ \\
\hline year & -0.008 & 0.007 & -1.088 & 0.298 & year & 0.022 & 0.004 & 5.967 & $6.54 \mathrm{E}-05$ \\
\hline SZSZB & estimate & std.error & t value & $\mathrm{p}$ value & SZSZB & estimate & std.error & t value & $p$ value \\
\hline (intercept) & -0.528 & 4.419 & -0.119 & 0.907 & (intercept) & -31.262 & 4.187 & -7.466 & $3.03 \mathrm{E}-06$ \\
\hline year & 3.19E-04 & 0.002 & 0.145 & 0.887 & year & 0.016 & 0.002 & 7.514 & $2.82 \mathrm{E}-06$ \\
\hline
\end{tabular}

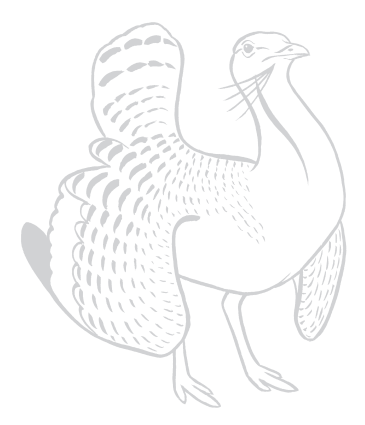

